\title{
Nova saznanja i problemi u proučavanju mramora (stećaka) sa teritorije Srbije
}

EMINA ZEČEVIĆ

Narodni muzej u Beogradu

E-pošta: e.zecevic@narodnimuzej.rs
UDK: $726.825(497.1) " 04 / 14 "$ 904:726.825](497.1)"04/14"

Pregledni rad

Primljeno: 14. ožujka 2020.

Prihvaćeno: 10. lipnja 2020.

Lektorica Tatjana Korićanac

\section{Sažetak}

U poslednjoj deceniji je na području zapadne Srbije, koje se u stručnim i naučnim krugovima označava kao teritorija stećaka, arheološki sondažno istraženo svega nekoliko grobalja, evidentiranih kao nekropole stećaka. Među njima su i tri istog toponima - Mramorje - u srednjem Podrinju (opština Bajina Bašta). Rezultati ovih i, po prvi put, objavljenih rezultata sa ranijih iskopavanja dve nekropole stećaka u donjem Polimlju (opština Priboj) pružili su nova, kao i potvrdu dosadašnjih saznanja u pogledu načina sahranjivanja, datovanja, ali i postojanja crkve uz groblje sa tipičnim poznosrednjovekovnim oblicima spomenika. Ujedno su obnovila problematiku izučavanja stećaka sa teritorije Srbije, nastalu usvajanjem tog termina za sve srednjovekovne

* Sažetak predavanja izložen je na skupu: "Stećci u 21. stoljeću - nove spoznaje i mogućnosti interpretacije", održanom 17. listopada 2019. u Mostaru. 
kamene nadgrobne monolite u Bosni i Hercegovini, koji su potom izučavani kao posebna "vrsta" spomenika u odnosu na spomenike u okruženju, kao i zbog poznate činjenice da su jedino sva groblja u Srbiji, koja su u repertoaru spomenika imala slemenjak, tretirana kao nekropole stećaka, a da su od brojnih istovremenih nadgrobnika drugih oblika samo pojedini svrstavani u stećke, iako među njima postoji evidentna srodnost u ornamentici, sadržaju epitafa ili načinu sahranjivanja.

Otkrića novih spomenika i lokacija sa srednjovekovnim kamenim nadgrobnicima u novijim rekognosciranjima terena ukazala su na neophodnost sistematskog evidentiranja i uspostavljanja jedinstvene tipologije oblika, potom arheoloških iskopavanja i uključivanja interdisciplinarnih istraživanja, ali i preispitivanja opravdanosti svih kategorizacija sa kojima su stećci ušli u nauku, pa i samog termina stećak.

Ključne reči: Srbija; groblja; stećci ili mramori različitih oblika; pozni srednji vek.

Istorijat istraživanja, pregled i problematika izučavanja poznosrednjovekovnih monolitnih kamenih nadgrobnih spomenika sa teritorije Srbije, koji su evidentirani pod terminom stećak, bili su tema svega nekoliko publikacija. ${ }^{1} \mathrm{~S}$ druge strane, postoji mnoštvo radova u kojima su kameni nadgrobnici srednjeg veka sa teritorije današnje Srbije obrađeni, a da se termin stećak ili ne pojavljuje ili se koristi u kontekstu upoređivanja ornamentike i sadržaja epitafa koji se pojavljuju na stećcima, a javljaju se i na "drugim" spomenicima koji su uglavnom navođeni prema obliku. ${ }^{2}$

1 ŠEFIK BeŠLAgić, Stećci, kataloško-topografski pregled, Veselin Masleša, Sarajevo, 1971, str. 413-430; Емина Зечевић, Мраморје, стећци западне Србије, Srpsko arheološko društvo, Beograd, 2005, sa starijom literaturom; Ista, "Позносредњовековни надгробни споменици Средњег Подриња", u: Užički zbornik, 31-1, Užice, 2007, str. 5-28; IsTA, "Topografija stećaka u Srbiji", u: Jasminka Poklečki-Stošić (ed.), Stećci, Galerija Klovićevi dvori, Zagreb, 2008, str. 220-236.

2 Teško bi bilo moguće samo pobrojati takve radove budući da gotovo nema srpskog manastira ili crkve pri čijem istraživanju nisu otkrivena i kamena nadgrobna obeležja. Navešćemo samo monografska izdanja posvećena srednjovekovnim nadgrobnim spomenicima sa teritorije Srbije u kojima je pobrojan i veliki broj radova na ovu temu: Никола Дудић, Стара гробла и надгробни белези у Србији, Prosveta, Beograd, 1995; Јелена Ердељан, Средюовековни 
Samo iz ove činjenice se vidi da je problem u izučavanju srednjovekovnih nadgrobnih spomenika iz Srbije u tesnoj vezi sa pojmom stećak, odnosno usvajanja tog termina za sve kamene nadgrobne srednjovekovne spomenike sa teritorije Bosne i Hercegovine, što je autorka ovog rada više puta isticala. ${ }^{3} \mathrm{U}$ vezi s tim je i opšte usvojeno stanovište u stručnim i naučnim krugovima da se samo deo teritorije Srbije - zapadna Srbija - označava kao teritorija stećaka, iako je od samih početaka zanimanja za stećke bilo poznato da van tog područja, odnosno na gotovo celoj teritoriji Srbije, postoji veliki broj srednjovekovnih nadgrobnih kamenih belega koji se mogu porediti sa stećcima na "matičnom" bosansko-hercegovačkom tlu.

Kada govorimo o novim saznanjima o nekropolama uvrštenim u nekropole stećaka, u najkraćem ćemo predstaviti tri groblja uz koja se vezuje isti toponim - Mramorje, a koja se nalaze na području zapadne Srbije i arheološki su istražena tokom poslednje decenije. Osvrnućemo se i na dva groblja sa mramorima sa teritorije jugozapadne Srbije, sa čijih iskopavanja su tek u novije vreme objavljeni rezultati. Reč je o grobljima istraženim uglavnom sondažno, koja u repertoaru spomenika imaju obavezno zastupljen oblik slemenjaka. Pokazalo se, naime, da slemenjak u evidencijama predstavlja jedini čvrst i pouzdan reper ne samo za datovanje groblja u pozni srednji vek, već i za "kategorizaciju" spomenika i grobalja na kojima se oni pojavljuju u stećke, što je rezultiralo i time da se kod pojedinih srpskih istraživača samo slemenjaci i forme spomenika slične njemu (na primer spomenici tipa "riblja leđa") nazivaju stećci-

надгробни споменици у области Paca, Arheološki institut Beograd i Muzej "Ras", Novi Pazar, Beograd, 1996; Драган Ђукић - Милан Ивановић, Стари надгробни споменищи и ирква на српском гробъу у Горюој Брнищи код Причтине, Zavod za zaštitu spomenika kulture Priština, Priština, 1996; Марина Бунарџић, Прибојско мраморје, српска средюовековна гробља, Republički zavod za zaštitu spomenika kulture Beograd, Beograd, 2017. Up. Е. Зечевић, Мраморје, стећии западне Србије, str. 22 i katalog lokaliteta na str. 92-175. Na primer za nadgrobne belege sa područja Starog Rasa se kaže da po mnogim svojim odlikama "stoje najbliže onoj vrsti nadgrobnih belega za koje je u nauci prihvaćen termin stećak", ali i da bi se izbegle "neželjene implikacije i terminološka dvoznačnost" svi ovdašnji spomenici koji predstavljaju pandan stećcima su analizirani pod opštom odrednicom - kameni nadgrobni spomenici (J. Ердељан, nav. d., str. 10 i nap. 2).

3 Емина Зечевић, "О pojmu stećak", u: Glasnik Srpskog arheološkog društva, 17, Beograd, 2001, str. 143-152; IsтA, "Три мраморја у околини Бајине Баште - прва истраживања", u: Glasnik Srpskog arheološkog društva, 33, Beograd, 2017, str. 123 i nap. 3. 
Emina Zečević - Nova saznanja i problemi u proučavanju mramora (stećaka)...

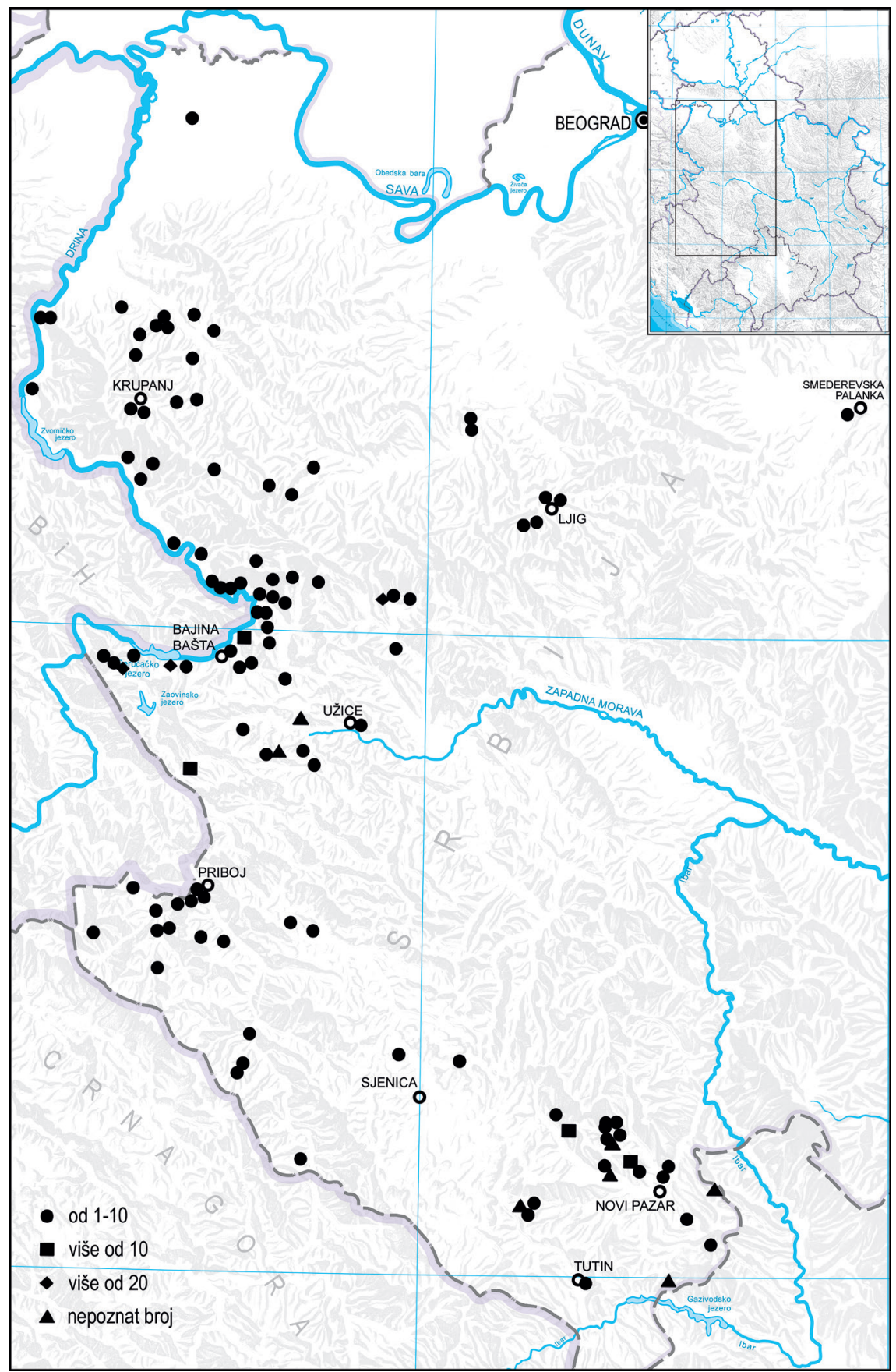

Karta 1. Rasprostranjenost i brojno stanje spomenika u obliku slemenjaka u Srbiji 
$m a{ }^{4}$ Iako broj lokaliteta sa slemenjacima, predstavljen na našoj karti, sigurno nije i konačan, jasno je da slemenjaka u najvećem broju zaista ima u zapadnoj i jugozapadnoj Srbiji (karta 1). ${ }^{5}$ Grupacija lokaliteta sa slemenjacima u oblasti oko Novog Pazara zapravo predstavlja u većini groblja na kojima je prisutan specifičan oblik spomenika svrstan u tip niskog pločastog slemenjaka, opisivanog i kao ploča sa gornjom površinom klesanom na dve vode, ${ }^{6}$ te bi se moglo govoriti o njima kao o specifičnim oblicima spomenika ove regije, a verovatno i ishodištu iz jedne ili nekoliko ovdašnjih klesarskih radionica. Na tim istim, i na drugim grobljima na ovom području, javljaju se i belezi koji su zbog svog oblika nazvani tipom "riblja leđa"; oni su tipološki određeni u poseban tip položene ploče sa ispupčenom gornjom površinom (među kojima su tek pojedini posmatrani kao podvrsta niskih pločastih slemenjaka), ${ }^{7}$ ili

4 Даница Поповић - Јелена Ердељан, "Старо гробље у Балетићу - резултати прелиминарних истраживања", u: Novopazarski zbornik, 13, Novi Pazar, 1989, str. 73-77, Table I-III. U opisu se navodi da su to monolitni (pseudo) sarkofazi u vidu sanduka sa dvoslivnim krovom, sa ili bez postolja, dok su spomenici u obliku "ribljih leđa" zapravo niski slemenjaci ponekad sa povijenim grebenom, koje pominje i Bešlagić pod terminom pločasti slemenjak, kao varijantu slemenjaka, a kojih ima u Bosni kao i u Srbiji kod Kraljeva (ŠEFIK BeŠLAGIć, Stećci - kultura i umjetnost, Zavod za izdavanje udžbenika, Sarajevo, 1982, str. 94, T. IV/1g); up. Даница Поповић, "Старо гробље у Вапи код Сјенице", u: Novopazarski zbornik, 20, Novi Pazar, 1996, 34 i dalje; J. Ердељан, nav. d., str. 10 sa nap. 2, str. 42, 46-49, 91-92 gde se u sistematizaciji oblika navodi Stećak (slemenjak), koji se primenjuje u "svom najužem, osnovnom tipološkom značenju" (Isto, str. 47); Жељко Јеж, "Некропола Дићи, прилог познавању средњовековних надгробних споменика", u: Saopštenja, XXII-XXIII, Beograd, 2000-2001, str. 140 sa nap. 20.

5 Kartiranje grobalja na kojima ima ili je bilo slemenjaka sačinjeno je na osnovu objavljene građe (prerađena i dopunjena karta 3 iz: Е. Зечевић, Мраморје, стећци западне Србије, str. 40). Zahvaljujem se koleginici Verici Tanasić na neobjavljenom podatku o slemenjaku na lokalitetu Staro groblje u Malom Zvorniku.

6 J. Ердељан, nav. d., str. 45-46, 92, sl. 10/1-4, u tipologiji izdvojen od oblika Stećak (slemenjak); Е. Зечевић, Мраморје, стећии западне Србије, str. 41, Tabela 3/1e - varijanta pločasti slemenjak; Драгица Премовић-Алексић, Археолошка карта Новог Пазара, Тутина и Сјенице, Muzej "Ras" Novi Pazar, Novi Pazar, 2014, str. 32 (lok. 27), 64 (lok. 95), 67 (lok. 105), 68 (lok. 108), 72 (lok. 119), 153 (lok. 312), 154-155 (lok. 317), 165 (lok. 337), 236 (lok. 519). Kod Š. Bešlagića je izdvojena podvrsta pločastog slemenjaka (Š. BEŠLAGIĆ, Kultura i umjetnost, str. 96 i tabela IV/1g).

7 J. Ердељан, nav. d., str. 46-47, 91-92. Najobuhvatniji pregled spomenika tipa "riblja leđa" na teritoriji Starog Rasa se nalazi kod: Д. Премовић-Алексић, nav. d. Oni nisu kartirani na ovde priloženoj karti 1. 
su svrstani u posebnu varijantu niskog slemenjaka sa lučno povijenom grebenom linijom. ${ }^{8}$ Kako god oni bili klasifikovani, ostaje činjenica da su karakteristični za teritoriju jugozapadne Srbije, ali da takvih ploča sa reljefno profilisanom gornjom površinom ima i izvan ovog područja, dalje na jugoistok, na teritoriji današnjeg Kosova i Metohije, o kojima će još biti reči, ali i u znatno udaljenijoj oblasti severozapadne Srbije. Naime, predstavljaju najbrojnije zastupljenu varijantu ploče na groblju u selu Dići kod Ljiga (lokalitet Manastirine), formiranom oko crkve koju je podigao čelnik Vldrag pre treće decenije 14. veka, otkrivenim u broju od preko 170 primeraka, i ukrašenih raznim motivima.' Za ovakve pojave, jer se ne radi o pojedinačnim primercima, još uvek nemamo pojašnjenja, i ona iziskuju mnogo bolju istraženost područja. Takođe se iz primera opisa i klasifikacija ovih nekoliko navedenih oblika spomenika pokazuje da standardi i jasna tipološka klasifikacija nadgrobnih spomenika sa teritorije Srbije nedostaju. Jedan od bitnih uzroka takvog stanja predstavlja loše dokumentovanje ili, uopšte, izostanak fotografija i crteža spomenika, tako da se oslanjanjem samo na opise, veoma često površne, naročito u radovima starijih istraživača, može doći do pogrešnih zaključaka. Otuda je revizija starijih podataka u ličnoj opservaciji terena neophodan i nezamenjiv vid istraživanja.

U nastojanjima da pokažemo koji su spomenici sa tla današnje Srbije nazivani stećcima i šta je zapravo proizvelo to svrstavanje spomenika u stećke kao posebnu "vrstu", ${ }^{10}$ koristićemo termin mramor, ne kao zamenu termina stećak već iz razloga što je mramor (je) opšti, ali i prirodan i najpodesniji termin za bilo koji oblik kamenog nadgrobnog belega, pri tome u praksi, tj. na terenu, i najčešći naziv za groblja sa kamenim nadgrobnicima.

Planska sondažna iskopavanja tri groblja u okolini Bajine Bašte (karta 2), u srednjem Podrinju, koja u nazivu imaju upravo Mramorje, a zabeležena su pod kategorijom stećaka, pružila su nova saznanja i potvrde u pogledu datovanja spomenika, ali i postojanja crkve uz groblje sa ti-

8 Е. Зечевић, Мраморје, стећии западне Србије, str. 41 sa nap. 40, Tabela 3/1ž.

9 Ж. Јеж, nav. d., str. 135-147. Od 127 grobova, sa više od 200 individua, samo su u tri nađeni novčići, u jednom grobu srebrna karičica, a u nekoliko njih par dugmadi i klinovi, koji, nažalost, nisu prikazani (Isto, str. 141).

10 Stećci se kao izričito posebna vrsta pominju i kod najvećih poznavaoca nadgrobnih spomenika sa tla Srbije (Д. Поповић - J. Ердељан, nav. d., str. 73), pa i kroz opise spomenika u većini objavljenih radova koji beleže kamene nadgrobnike, počev od prvih njihovih istraživača (up. Е. Зечевић, Мраморје, стећии западне Србије, str. 22 i opisi u katalogu lokaliteta na str. 92-175). 
Hercegovina - 6 - 2020., str. 63-98

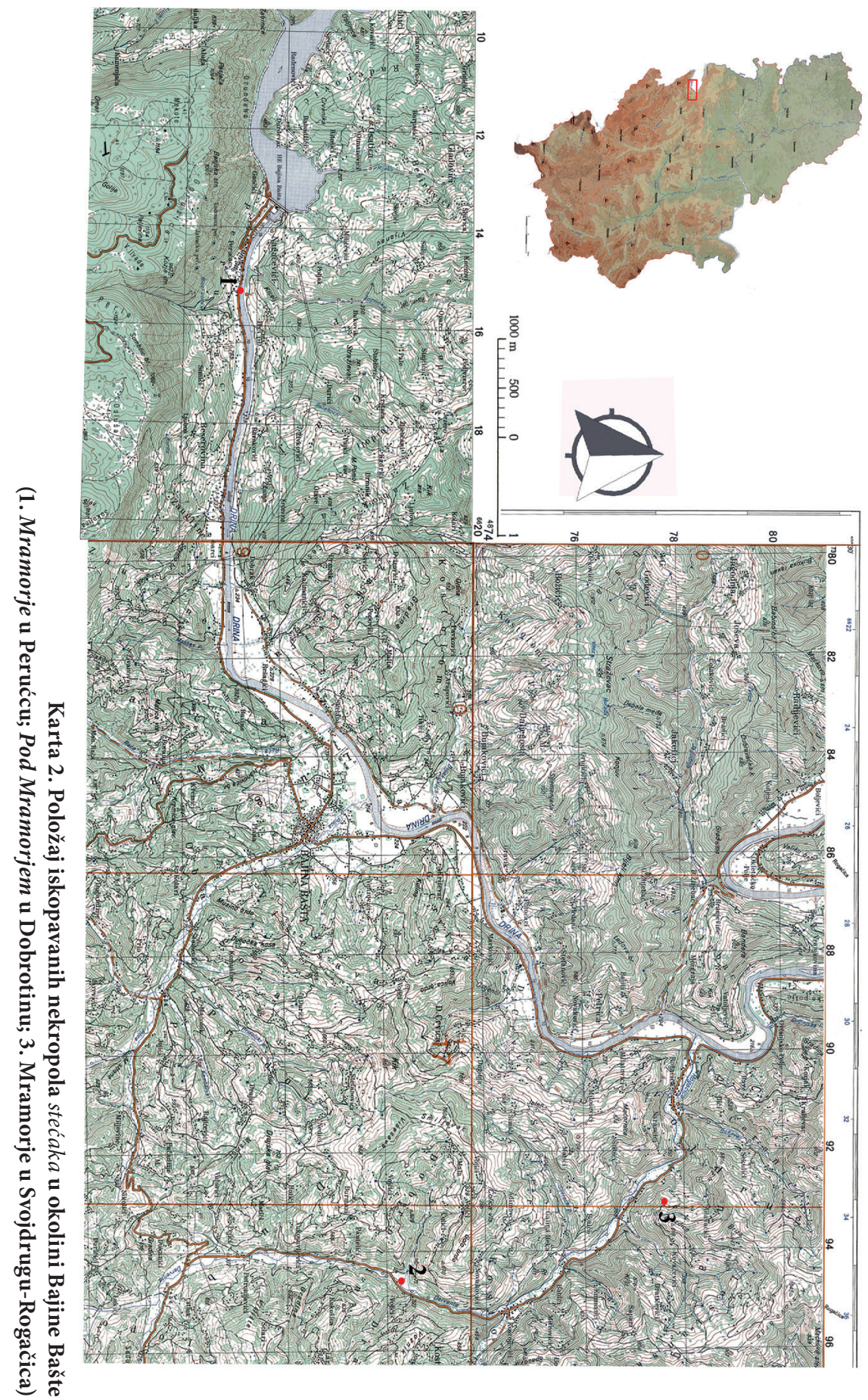


pičnim poznosrednjovekovnim oblicima nadgrobnih belega. ${ }^{11}$ Ukratko ćemo izložiti rezultate ovih iskopavanja. Nekropola na potezu Mramorje u Perućcu, zapadno od Bajine Bašte, u okviru projekta međudržavne serijske nominacije stećaka upisana je na Listu svetske baštine (2016). Nekropola je konstantno izložena devastiranju, te se broj zabeleženih spomenika $s$ vremenom drastično smanjivao sudeći po raspoloživim podacima (od prvog popisa kod Kanica sa 200 spomenika do Bešlagićevih 93). U literaturi postoji podatak o nalazu nakita 12-13. veka, koji nije potvrđen ovim iskopavanjima, koja su bila manjeg obima i sondažnog karaktera (sonde 1-2/2010). Na nekropoli se danas može videti 88 mramora različitih oblika koji formiraju pravilne redove u više nizova. Zastupljeni su oblici ploče, sanduka i slemenjaka, sa ili bez postolja, i dvojne ploče (slika 1). U sondi 1 podignuto je četiri mramora, a konstatovane su ivice još tri ukopa u prostoru oko i između spomenika, od kojih je jedan ispražnjen (grob 5). Ispod dva slemenjaka s postoljem istraženi su grobovi 1 i 3 , sanduk je stajao iznad groba 2, a ploča $s$ postoljem iznad groba 4 . Reč je o pravougaonim rakama, dubine do 1,6 m, sa ostacima pokojnika prekrivenih debelim drvenim daskama u uobičajenom položaju, orijentacije zapad-istok sa devijacijama (slika 2). Pokojnici su različitog pola i starosti. U grobu 5 nađen je novčić,

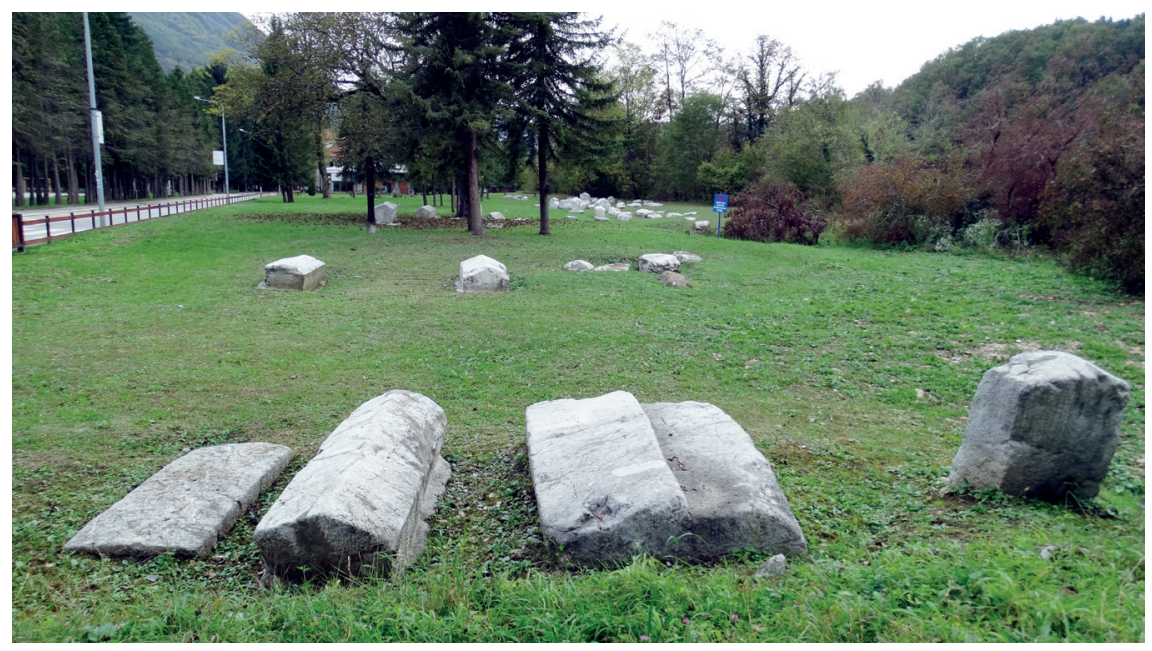

Slika 1. Lokalitet Mramorje u Perućcu, pogled sa istoka (foto E. Zečević, 2016.)

11 Rezultati iskopavanja, vršenih u okviru projekta "Podrinje u poznom srednjem veku" Narodnog muzeja u Beogradu, objavljena su u vidu preliminarnog izveštaja od strane rukovodioca projekta: Е. Зечевић, Три мраморја $y$ околини Бајине Баште, str. 121-147. 


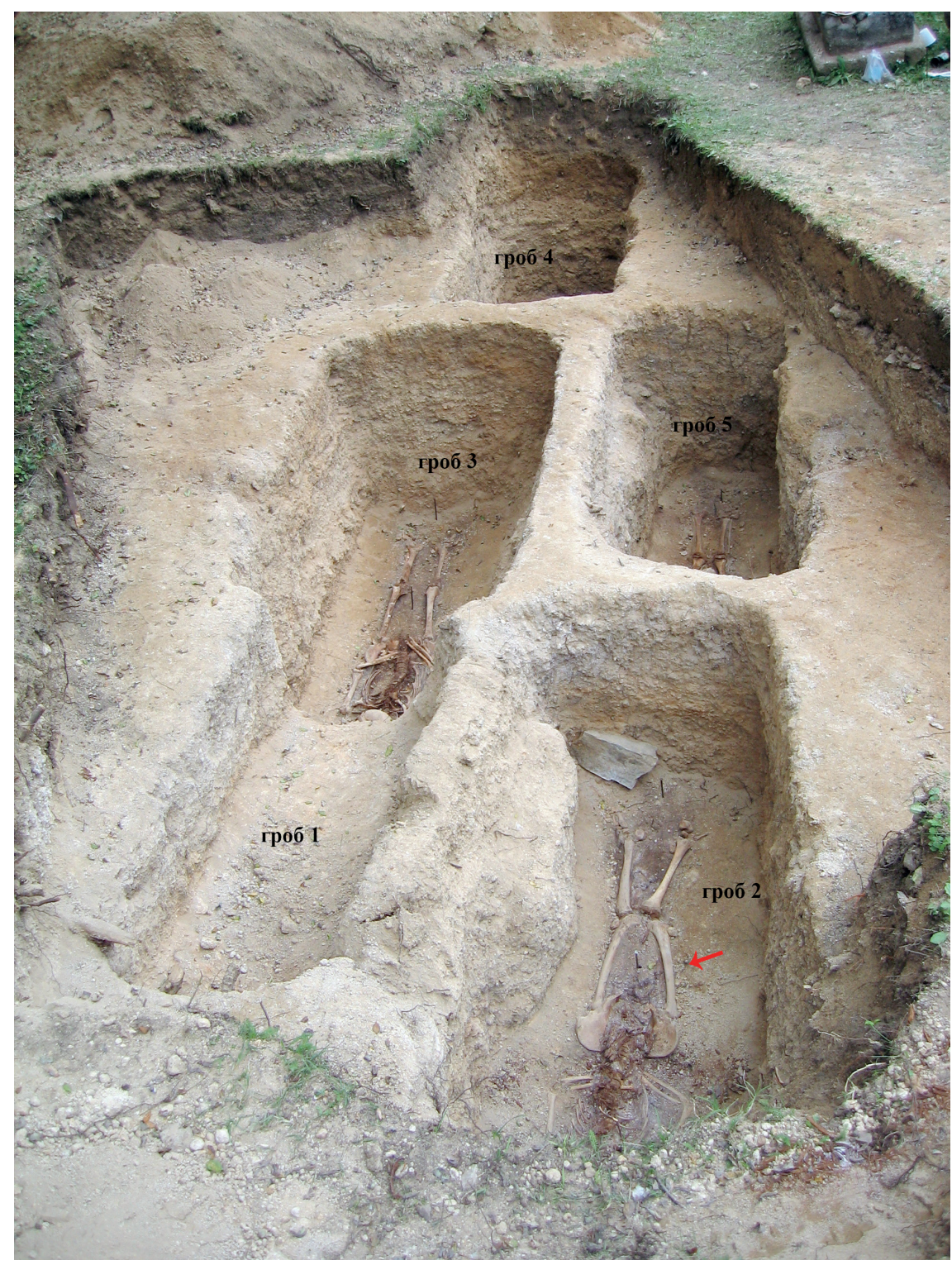

Slika 2. Lokalitet Mramorje u Perućcu, sonda I/2010, osnova iskopa

poludinar (?) srpskog despota Đurđa Brankovića (drugi period despotskog razdoblja, između 1435. i 1456). U sondi 2 podignuta su dva slemenjaka s postoljem (na "ležištima" od kamena) i istraženi grobovi 6-7 pod mramorima, grob 8 i delimično 9 (zalazi u profil) bez mramora, a uočene ivice još četiri grobne rake koje nisu pražnjene. U grobu 
Emina Zečević - Nova saznanja i problemi u proučavanju mramora (stećaka)...

7, pod jednim slemenjakom sa postoljem, otkriven je dinar bosanskog kralja Stefana Tomaša (1443-1461), a u grobu 8, iznad kojeg nije bilo nadgrobnog obeležja, otkriveno je i nekoliko trošnih i sitnih ulomaka keramike grube fakture od više posuda. ${ }^{12}$

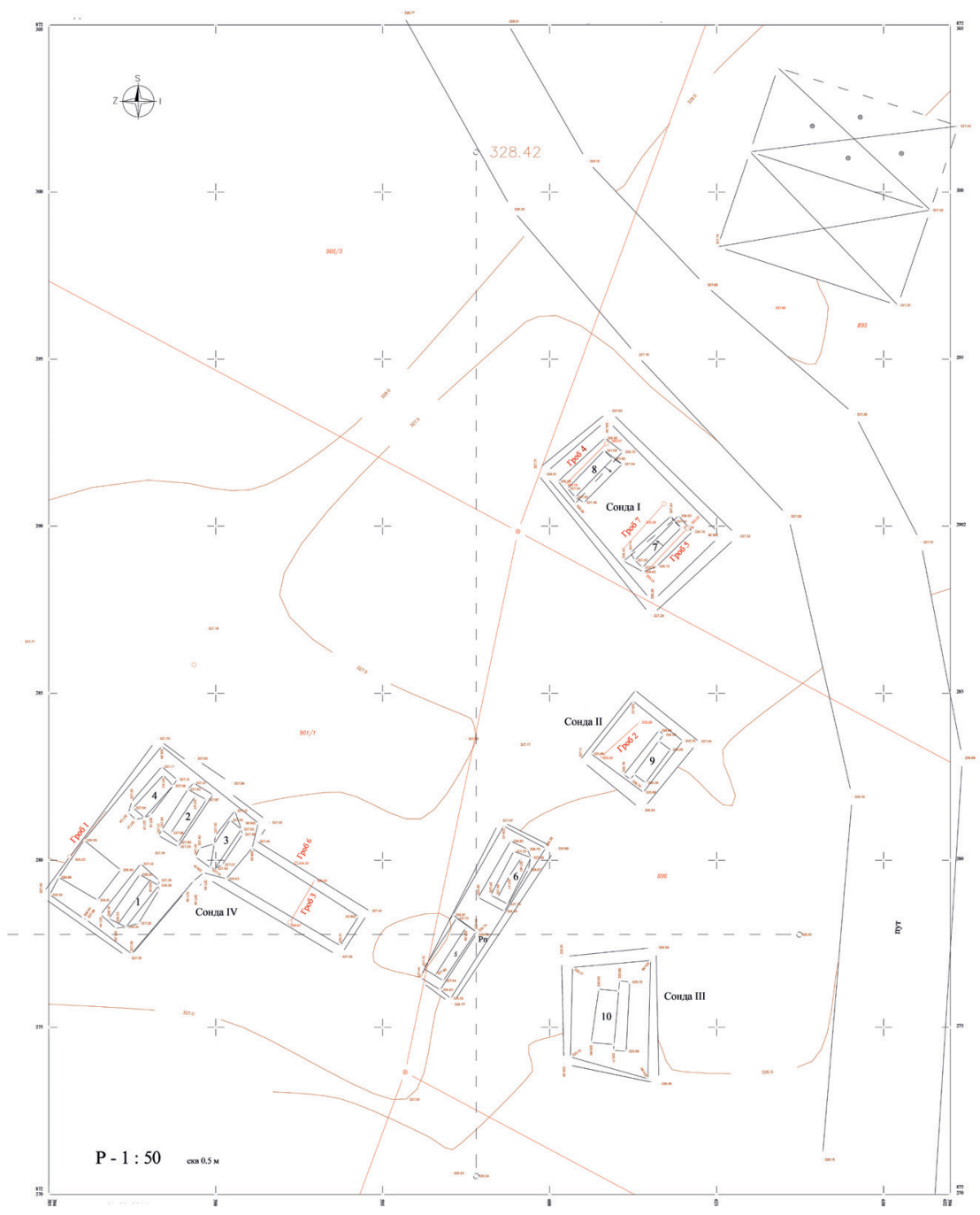

Slika 3. Lokalitet Pod mramorjem, selo Dobrotin, situacioni plan sa položajem sondi (foto 2014.)

12 Isto, str. 124-130. Iako planiran, nastavak iskopavanja nije realizovan (Isto, str. 129 sa nap. 10). 
U selu Dobrotin, u zaleđu desne obale Drine, na potezu Pod mramorjem, tokom 2014. godine obavljeno je sondažno iskopavanje (sonde I-IV) oko dve vidljive skupine od ukupno pet slemenjaka sa postoljem (br. 1-3, 5-6), uz koje se sišlo do nivelete prvobitnog terena. Ispod površine terena, pod slojem rečne naplavine debljine od 1,5 do $2 \mathrm{~m}$ otkrivena su još 2 sanduka i 3 slemenjaka, svi sa postoljima (br. 4, 7-10), koji su po završetku radova podignuti na sadašnju površinu terena iznad prvobitnog mesta (slika 3). Pod postoljima većine spomenika, čije se težine kreću od 3 do 4,5 tone, otkrivena su "ležišta" od komada lomljenog kamena i oblutka. Istraženo je ukupno 7 grobova, od čega tri pod podignutim spomenicima, dok su ostali grobovi otkriveni ispod površina gde nije bilo spomenika, ali u položaju između ili pored njih, u pravilnom nizu. Samo pod novootkrivenim (oborenim) sandukom br. 10 grob nije pronađen, jer se iz bezbednosnih razloga stalo sa iskopavanjem na 2,7 m dubine. $U$ grobu 4 otkriven je kamen složen u 2-3 reda, a u većini se uz skelete pojavljuje pojedinačno kamenje. Grobovi su bez priloga. Otkrivena su svega 2-3 sitna ulomka grnčarije u grobu 2. Orijentacija grobova je dvojaka, po pravcu severoistok-jugozapad, odnosno jugozapad-severoistok, pokojnici su sahranjeni u običajenom položaju - opruženi na leđima, sa glavom na potiljku, prekrštenih ruku. Samo je jedan slemenjak (8) imao ornament na slemenu u vidu reljefne predstave polumeseca (slika 4$).{ }^{13}$

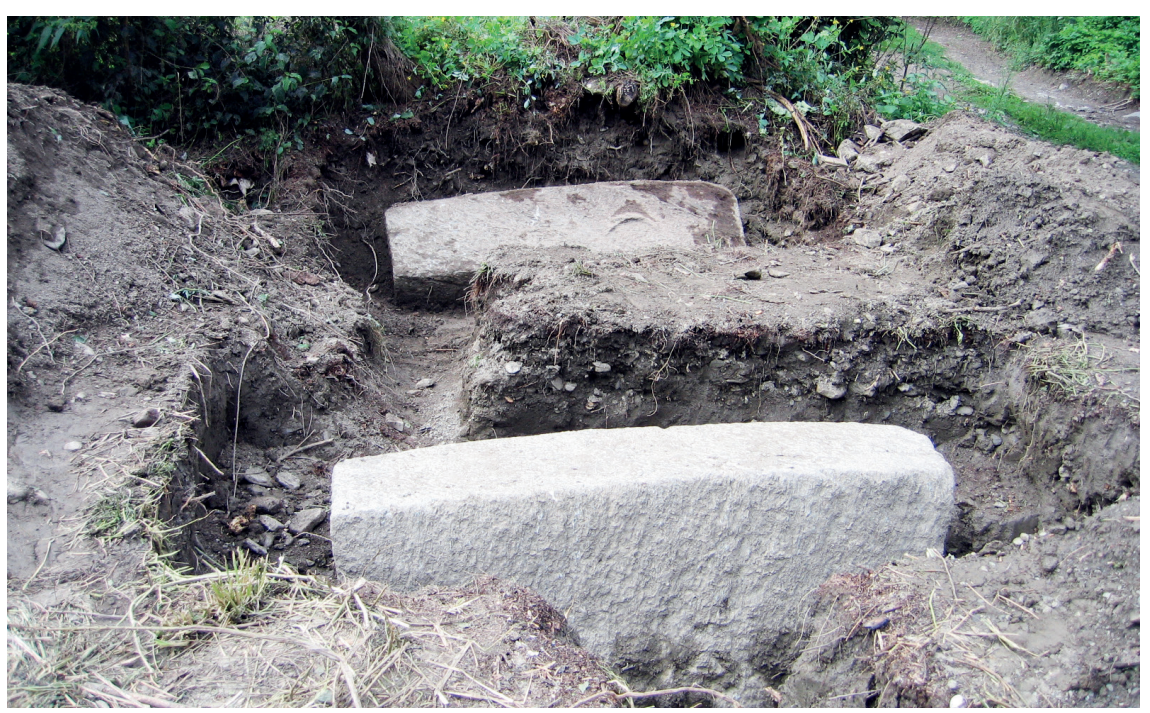

Slika 4. Lokalitet Pod mramorjem, selo Dobrotin, otkrivanje slemenjaka 8 i 9 pod slojem rečne naplavine (sonda $\mathrm{I} / 2014$ )

13 Isto, str. 130-136. 


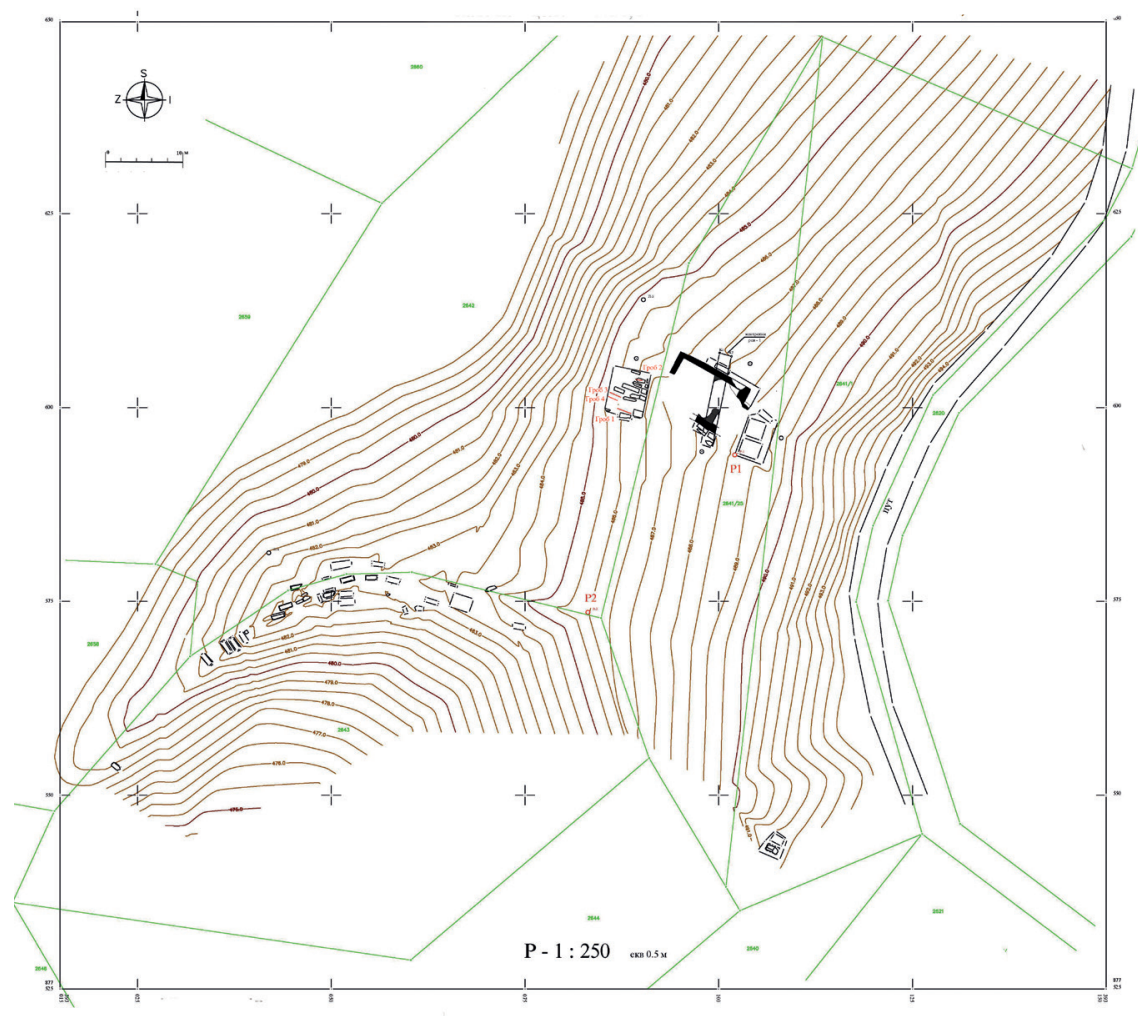

Slika 5. Lokalitet Mramorje, Rogačica-Svojdrug, situacioni plan sa položajem sondi

(foto 2015.)

U Svojdrugu (Rogačica), severoistočno od Bajine Bašte, na potezu Mramorje, tokom 2015. godine obavljeno je sondažno iskopavanje ruševine crkve sa delom groblja uz njene zidove (slika 5). ${ }^{14}$ Istovremeno su samo očišćeni delovi groblja na grebenu jugozapadno od crkve sa 24 spomenika u obliku ploča (od kojih je samo jedna ukrašena motivom dve reljefne rozete), i sanduka sa postoljem ili bez njega, kao i svega dva vidljiva mramora - slemenjak i ploča, južno od građevine. U sondi I, postavljenoj sa zapadne strane crkve, otkriveno je 14 mramora u obliku ploča i sanduka (br. 1-9, 15-19), i istražena su 4 groba (br. 1-4), uz više pojedinačnih kostiju drugih skeleta i dve grupe kostiju uz skelet groba 3 (devastirani grobovi) slika 6. Grobovi 1, 3 i 4, sa ostacima odraslih

14 Isto, str. 136-144. 


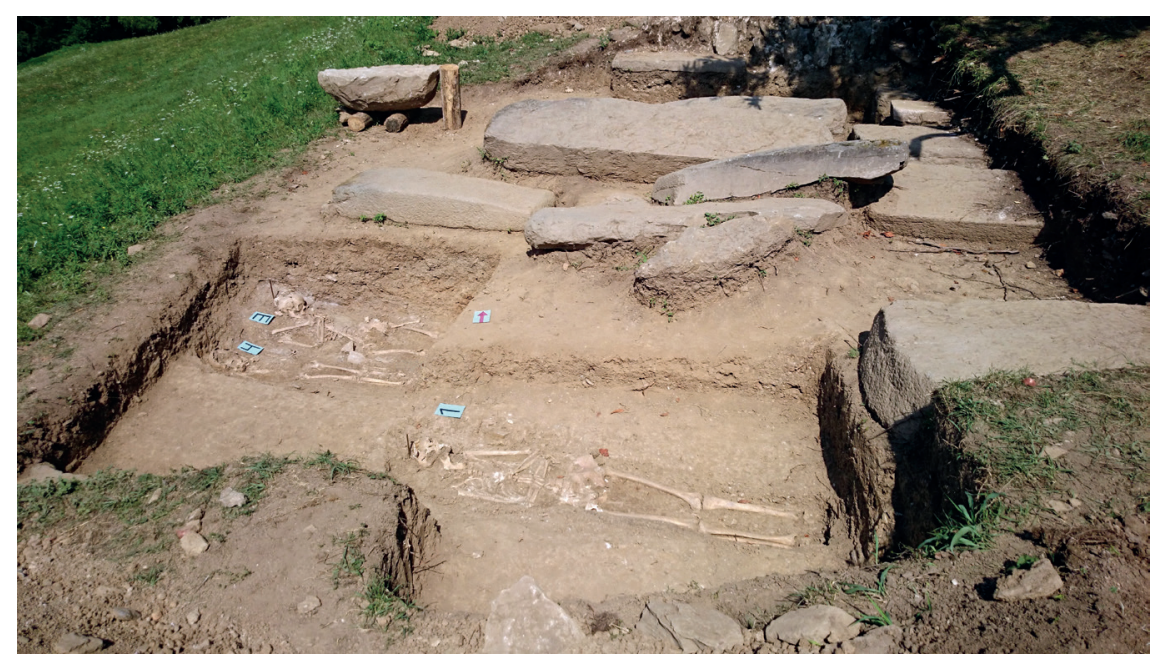

Slika 6. Lokalitet Mramorje, Rogačica-Svojdrug, sonda I/2015, osnova iskopa

individua oba pola i jednog dečijeg skeleta, otkriveni su plitko ispod sadašnje površine terena na kojoj nije bilo spomenika, ali u nizu sa njima. Nad dečijim skeletom u grobu 2, bez priloga, nađena je daska i sanduk ukrašen motivom dvostrukog stilizovanog krsta. Pokojnici u grobovima 1 i 4 su takođe imali dasku preko tela, dok su u grobu 3 otkriveni ostaci dve daske postavljene na dve vode iznad tela pokojnika. Nađeni su sitni ulomci grnčarije u zemlji kojom su ispunjene rake grobova $1 \mathrm{i}$ 3 , i jedan kovanik južno od groba 3 . Uz skelet pokojnika u grobu $1, \mathrm{u}$ predelu karlice, otkrivene su dve fragmentovane gvozdene alke kružnog oblika i pravougaonog preseka, kao i mali ulomak narukvice od gotovo neprozirnog crnog stakla.

Crkva je prva otkrivena poznosrednjovekovna sakralna građevina u ovom delu srednjeg Podrinja, i za sada jedina uz koju su otkriveni kameni monolitni nadgrobni spomenici. Zidovi ove jednobrodne građevine sa polukružnom apsidom na istoku i ulazom na zapadu, spoljnih dimenzija oko 7 x 13 m, samo su delimično otkriveni, zapravo ispraćeni u gotovo celom gabaritu kako bi se definisala njena osnova (slika 7). Izdvojene su dve građevinske faze, pri čemu se moglo utvrditi da je obnova izvršena pregradnjom istočnog dela unutrašnjeg prostora - dograđivanjem južne polukružne konhe i stuba od sige uz čeoni zid južnog luka i konhe uz naspramni zid. Unutar probnog rova kojim su otkriveni delovi južnog i severnog zida pod ruševinom u vidu humke, sa spoljne strane zidova, paralelno sa njima ležalo je pet spomenika u obliku ploče (br. 10-14). Uz ploču 13, uz južni zid građevine, koja je imala 


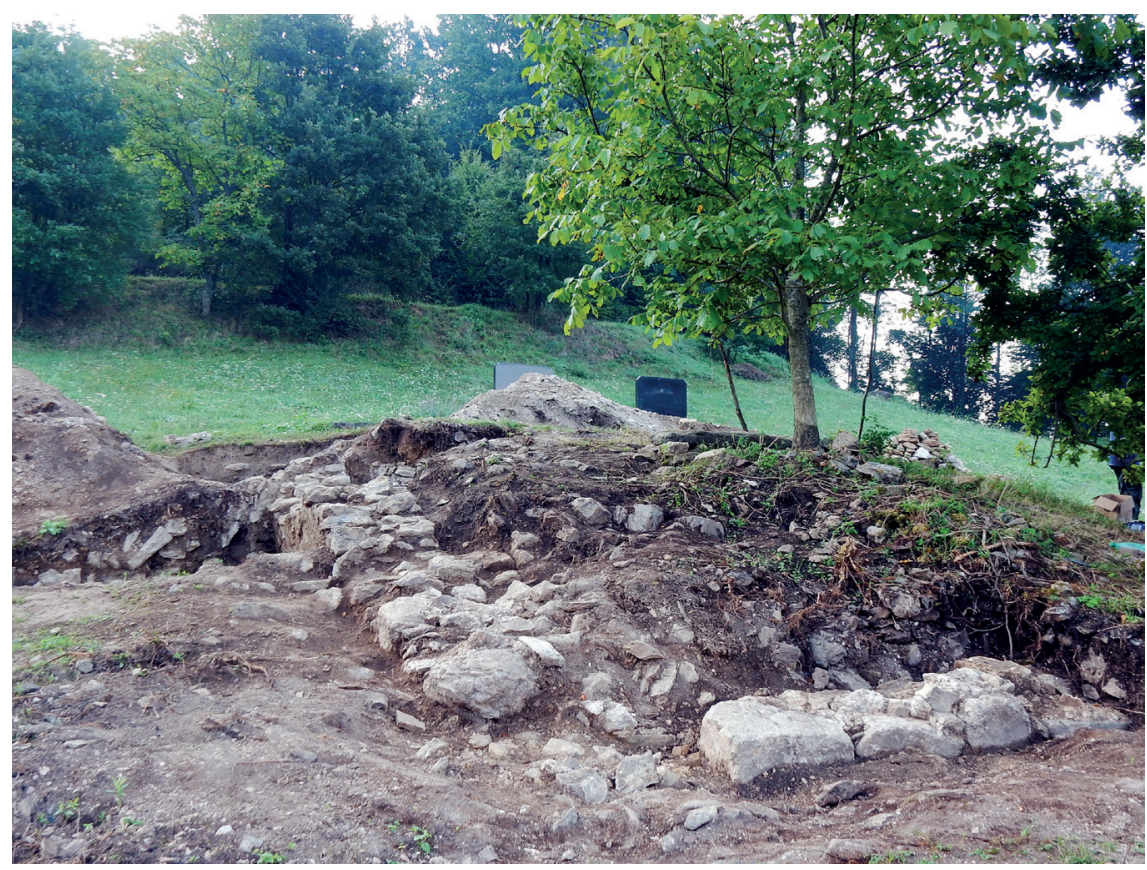

Slika 7. Lokalitet Mramorje, Rogačica-Svojdrug, ostaci crkve, pogled sa severozapada

uklesani ornament u vidu dve potkovice, nađen je još jedan kovanik. $U$ ogromnoj količini šuta unutar zidova i oko njih, u okviru pomenutog kontrolnog rova, pronađeni su profilisani komadi sige od kojih pojedini imaju sačuvane površine fresko živopisa, ali i velika količina usitnjenih ulomaka fresaka na debljem sloju maltera, koji su potvrdili da je reč o građevini 14-15. veka, zasigurno omalterisanoj u prvobitnoj fazi. Istovremeno se otkrićem ukupno 45 mramora pokazalo da je nekropola znatno veća nego što se moglo pretpostaviti na osnovu ranijih evidencija o brojnom stanju spomenika, ali je nerealizovan nastavak iskopavanja onemogućio dobijanje dodatnih podataka o sahranjivanju i u prostoru među vidljivim delovima groblja. ${ }^{15}$

U novije vreme objavljeni su po prvi put rezultati ranijih iskopavanja dve nekropole sa mramorima u donjem Polimlju ${ }^{16}$ - u samom Priboju na Limu, u Pobrežju, na lokalitetu Crkvine, koja u starijim pregledima nije evidentirana kao nekropola stećaka (a ima slemenjaka) i jednog

15 Isto, str. 142 sa nap. 16.

16 М. Бунарџић, nav. d., str. 18-19 sa nap. 22, 26-27. 


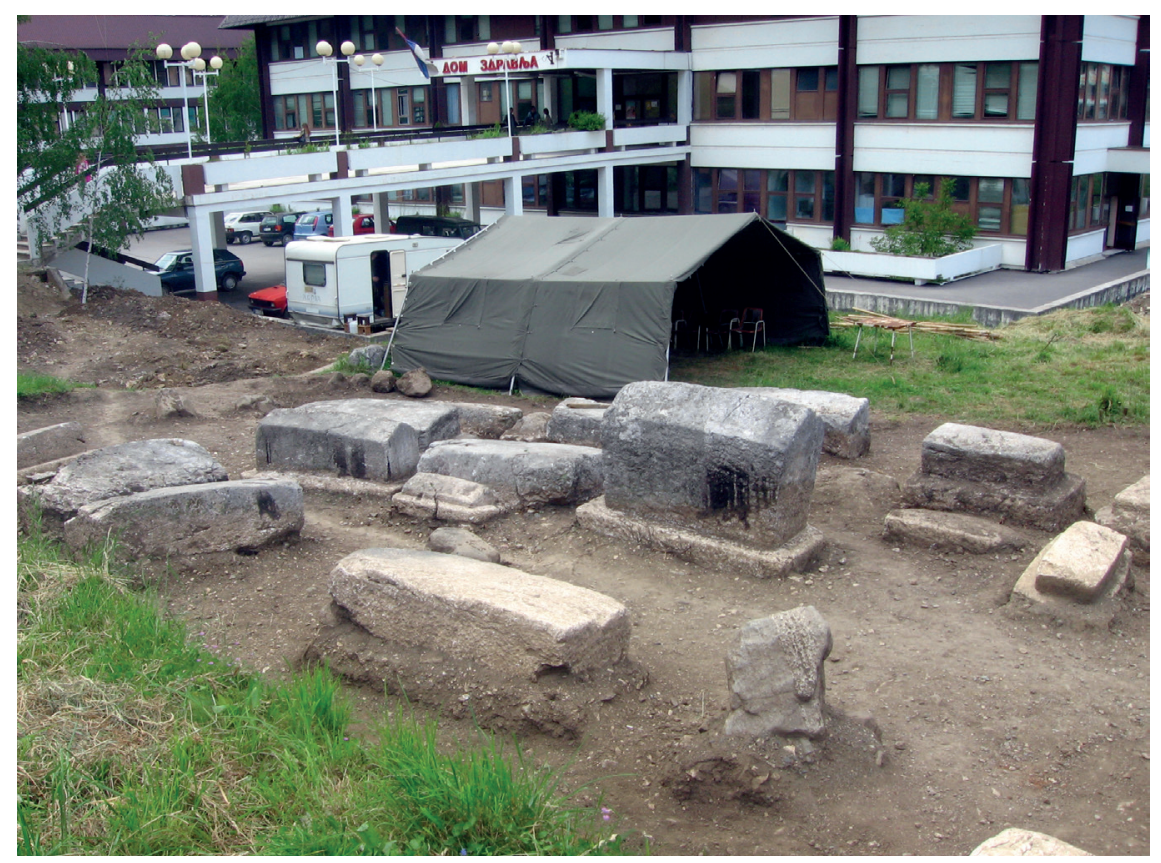

Slika 8. Lokalitet Crkvine u Priboju, pogled na deo nekropole sa mramorima tokom iskopavanja 2008. godine (foto E. Zečević)

groblja u selu Krajčinović, na lokalitetu Ocrkavlje, poznatom od ranije u evidenciji stećaka sa tla Srbije. ${ }^{17} \mathrm{Na}$ površini groblja sa mramorima u starom Priboju (Crkvine), u dva navrata su vršena arheološka iskopavanja i tom prilikom otkriven je ukupno 41 spomenik i istraženo 53 groba (11 ispod kamenih belega). ${ }^{18}$ Reč je o mramorima u obliku slemenjaka sa postoljem, sanduka sa i bez postolja, ploče sa postoljem i bez njega i mramora amorfnog oblika, različitih dimenzija (slika 8). Dominantan oblik je sanduk i sanduk sa postoljem. Svojevremeno je navodno

17 Š. BEŠLAGIĆ, Stećci, kataloško - topografski pregled, str. 424; Е. Зечевић, Мраморје, стећии западне Србије, str. 131-132 sa starijom literaturom (lok. br. 101. Krajčinovići, Seoska crkva).

18 Prve sondažne radove je 1982. godine sproveo Zavod za zaštitu spomenika kulture Kraljevo i Arheološki institut iz Beograda, a tokom 2008. godine Zavičajni muzej u Priboju je obavio sistematska istraživanja preostalog dostupnog dela groblja, budući da je ostao sačuvan samo deo njegove površine oivičene ulicama i zgradom bolnice, dok je deo devastiran izgradnjom bolnice, fabrike Poliester, urbanizacijom grada i tokom bujične vode obližnjeg potoka (M. Бунарџић, nav. d., str. 37-64). 
ovde nađen i jedan mramor sa ćiriličnim natpisom, danas zagubljen, ali to nije pouzdan podatak. ${ }^{19}$ Ornamentisano je samo četiri mramora predstavama krsta (sanduk), koncentričnog kruga (ploča sa postoljem), uklesanim linijama po sredini podužne strane (sanduk), mačeva, polu-

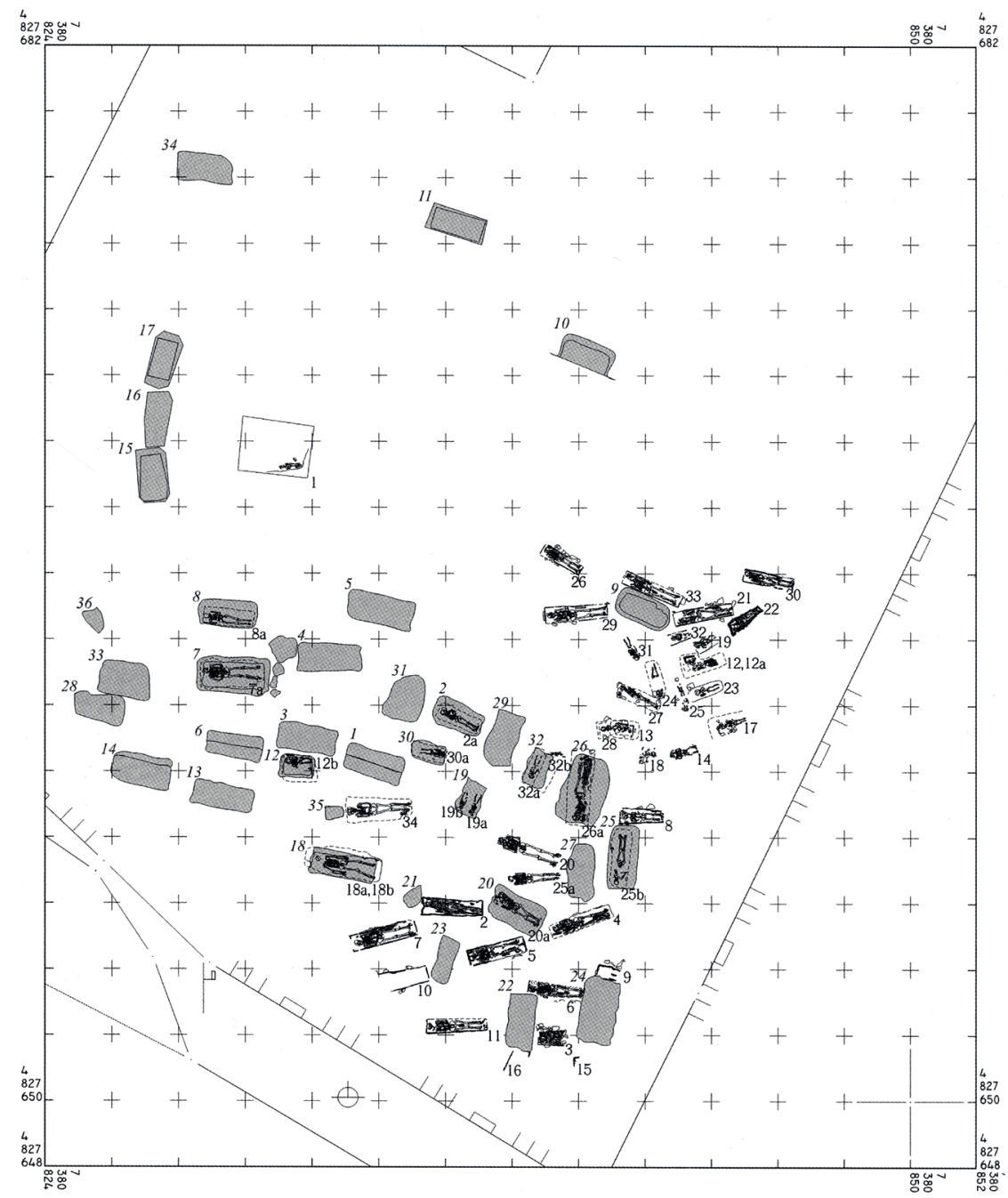

Slika 9. Lokalitet Crkvine u Priboju, situacioni plan (prema M. Bunardžić, Pribojsko mramorje, sit. plan 7)

19 Р. Бунарџић i dr., Топографија Полимља, I, Republički zavod za zaštitu spomenika kulture Beograd, Beograd, 2008, str. 110; up. М. Бунарџић, nav. d., str. 65 sa nap. 100. 
meseca i šematizovanog grba (visoki sanduk sa postoljem sa stepenasto oblikovanom gornjom površinom). U više slučajeva na (?) grobovima sa in situ mramorima je dokumentovana supstrukcija od sitnijeg i krupnijeg amorfnog kamenja, za koju se smatra da ima funkciju da izravna ulegnuća po sleganju zemlje kojom je raka ispunjena. ${ }^{20}$ Pokojnici su polagani u opruženom položaju, ruku položenih na stomaku, većinom u sanduke od drvenih dasaka. Konstatovano je ponovljeno sahranjivanje $\mathrm{u}$ istoj raci i nekoliko dvojnih grobova, kao i ostaci odraslih i individua dečijeg uzrasta (slika 9). U pojedinim grobovima je konstatovano kamenje oko sanduka, dok ivice ukopa uglavnom nisu uočene. Neobičan je primer konstrukcije od krupnog amorfnog kamena poređanog, približno u obliku elipse, oko jednog sanduka. ${ }^{21}$ Orijentacija većine grobova, sa odstupanjima, jeste po pravcu zapad-istok sa glavom na zapadu, ali su u tri groba pokojnici glavom bili na istoku, dok je u osam slučajeva grob ukopan po pravcu sever-jug, sa pokojnikom čija je glava ležala na južnom kraju groba. Zabeleženi su i tragovi pogrebnih običaja (ugljenisano drvo u ispuni rake, kosti živine i ljušture puževa), a od nalaza se pominju samo kovanici i tragovi tkanine. Međutim nisu konstatovani ostaci crkvene građevine iako bi se prema toponimu to moglo očekivati.

Druga nekropola u selu Krajčinovići, na lokalitetu Ocrkavlje, odnosno u porti crkve sv. Arhanđela Mihaila, je zanimljiva po tome što je groblje sa mramorima delom formirano na jednoj praistorijskoj humci (slika 10). ${ }^{22}$ Svojevremeno je registrovano 79 mramora, koji su dobrim delom izmešteni sa prvobitnih mesta, što je uočljivo i danas; brojno stanje spomenika se sudeći po ranijim evidencijama menjalo, ali se pominje da su

20 М. Бунарџић, nav. d., str. 63. Zapravo to kamenje ima funkciju "ležišta" za sam spomenik koja smo konstatovali tokom pomenutih iskopavanja pod mramorima u Perućcu i Dobrotinu, a koja inače predstavljaju jednu od karakteristika arhitekture grobova sa ovako masivnim monolitnim nadgrobnicima (Š. BEŠLAGIć, Stećci - kultura i umjetnost, str. 47).

21 М. Бунарџић, nav. d., str. 56-57, sl. 141-142 (mramor br. 18).

22 Iskopavanja Narodnog muzeja Užice obavljena su davne 1985. godine (M. Бунарџић, nav. d., str. 83-92). Ovo nije jedini primer srednjovekovne sahrane na praistorijskoj humci u ovom kraju. U selu Hercegovačka Goleša, gde su inače dva groblja već evidentirana kao nekropole stećaka (Isto, lok. br. 21 i 23; up. Е. Зечевић, Мраморје, стећии западне Србије, lok. br. 191 i 192), u zaseoku Crnetići u blizini seoske crkve, nalaze se još dva groblja koja nisu ušla u popis stećaka - jedno groblje sa pločama i pločastim usadnicima na samoj humci i oko nje, i drugo na kome su mramori u novije vreme polupani a sačuvao se samo jedan usadnik (М. Бунарџић, nav. d., str. 74). 


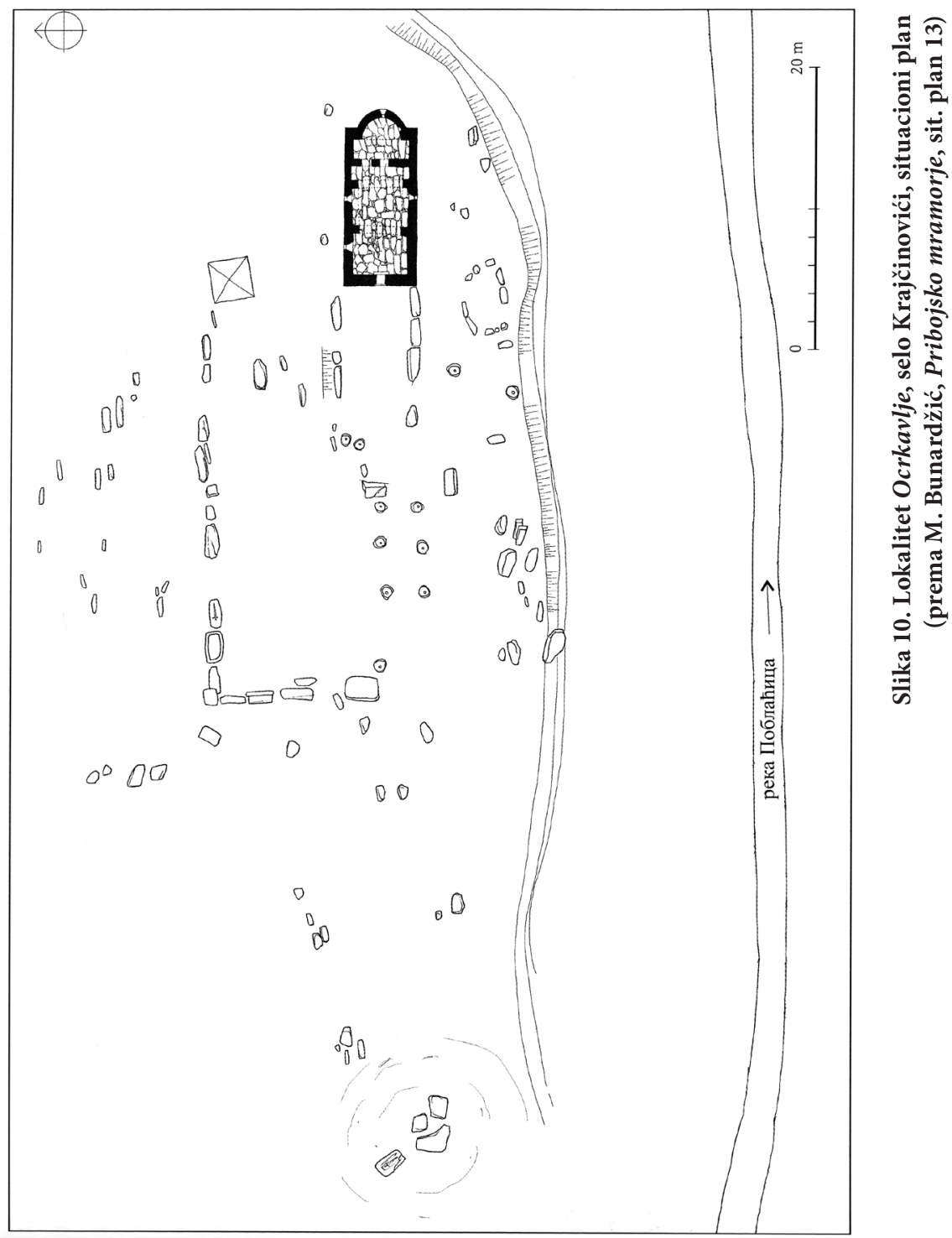

postojala i dva slemenjaka bez postolja, sanduci sa i bez postolja i ploče, kao i četiri spomenika sa reljefnim predstavama polumeseca, koplja, mača i dvojne sekire. ${ }^{23}$ Prilikom iskopavanja humke VIII konstatovano

23 U ovom poslednjem pregledu spomenika opisana su samo tri od četiri ukrašena i ranije publikovana sanduka (М. Бунарџић, str. 90), a beleži se i da su se jedan široki, možda dvojni spomenik, i jedan sanduk sa predstavom mača, 
je u njenoj zoni 16 grobova od kojih je istraženo 14 (svi bez nadgrobnih belega), među kojima i jedan dvojni grob. Na humci su se, naime, nalazila i dva spomenika koji su na užim stranama bili flankirani sa manjim usadnicima. U većini grobova su nađeni ostaci drvenih sanduka i kovanici, kao i amorfno kamenje ili obluci koji su ispunjavali prostor između ivice rake i sanduka. Pokojnici su sahranjivani u uobičajenom položaju - opruženi na leđima, ruku prekrštenih na stomaku, u pravougaonim rakama čije ivice nisu svuda mogle biti uočene, orijentacije zapad-istok sa glavom na zapadu, i većim ili manjim devijacijama uglavnom po pravcu jugozapad-severoistok, ređe zapad / severozapad-istok / jugoistok, a jedan i sever-jug sa glavom na jugu. Od pokretnih nalaza, u zasipu humke su nađeni komadi nakita i nošnje (bronzani prsten i srebrna karičica otvorenih krajeva, jedno šuplje liveno dugme), nažalost bez drugih bližih podataka i ilustracija koje bi ih dokumentovale.

I rekognosciranja izvedena u novije vreme pokazala su značajno veći broj srednjovekovnih grobalja sa mramorima u odnosu na poslednju evidenciju stećaka na teritoriji zapadne Srbije. Među njima ima i spomenika vrlo retkih i neobičnih oblika. Evo nekoliko podataka. Zahvaljujući novijoj publikovanoj građi znamo da je samo na pomenutoj teritoriji opštine Priboj u oblasti donjeg Polimlja, koje se inače ubraja u najstarije matične srpske zemlje, do sada registrovano око 35 nalazišta sa nadgrobnim kamenjem. ${ }^{24} \mathrm{U}$ srednjem Podrinju, samo u opštini Bajina Bašta, aktuelnim rekognosciranjima je otkriveno pet novih lokacija sa spomenicima u obliku slemenjaka (slika 11) i ploča, kao i više grobalja sa usadnicima kao jedinim oblikom, među kojima ima i onih za koje se može pretpostaviti datovanje u doba pre 16 . veka. ${ }^{25}$ Isti slučaj je sa teritorijom severozapadne Srbije, pa je tako, na primer, u opštini Osečina

sudeći po skici iz 1973. godine, pre pomeranja nalazili na humci (Isto, str. 86, sit. plan 13).

$24 \mathrm{Uz}$ ranije evidentirane 22 lokacije sa stećcima, još 13 novih nalazišta sa nadgrobnim kamenjem je popisano u obilascima terena koji je obavila ekipa Republičkog zavoda za zaštitu spomenika kulture (М. Бунарџић, nav. d., lok. br. $2,4-5,7-10,12,14,18,22,24-25)$. Kao rezultat velikog angažovanja i dobrog dokumentovanja, posebno značajnog jer se po prvi put objavljuju rezultati starijih iskopavanja dve pomenute nekropole, ova građa, nažalost, nije na najbolji način prezentovana i analizirana, ali je svakako korisna po pitanju preseka stanja i ispravke podataka proverenih na samom terenu, a pre svega kao dobra osnova za buduća istraživanja, up. prikaz knjige u: Glasnik Srpskog arheološkog društva, 33, Beograd, 2017, str. 371-378 (E. Zečević).

25 Dokumentacija Narodnog muzeja u Beogradu. 


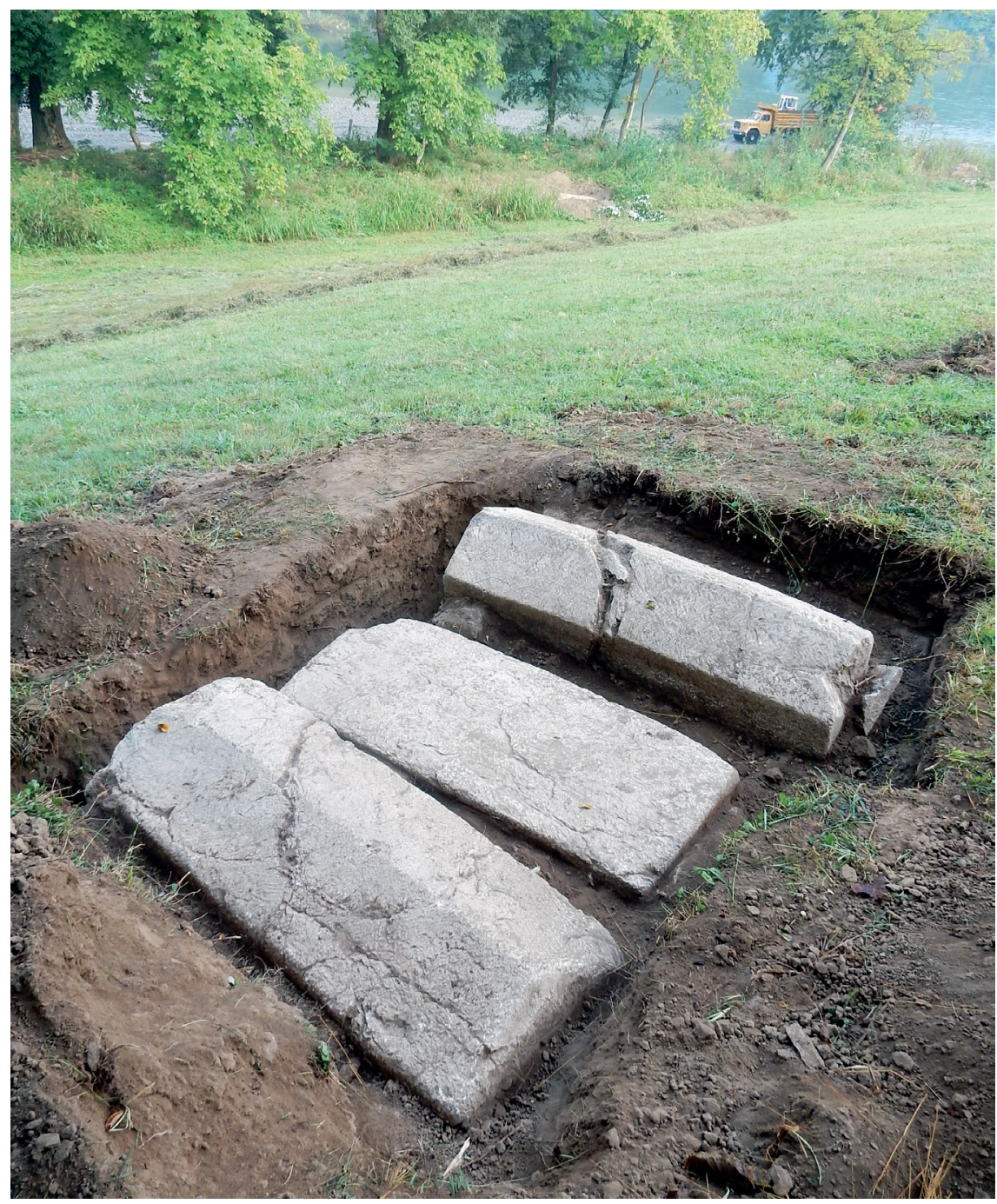

Slika 11. Lokalitet Rimsko groblje, Rogačica kod Bajine Bašte (foto E. Zečević)

i Bogatić pored samo tri ranije evidentirane lokacije sa mramorima u obliku ploča i sanduka, nađeno još deset u poslednjim rekognosciranjima terena. ${ }^{26} \mathrm{U}$ tom severozapadnom delu Srbije koji je ušao u ranije preglede nekropola stećaka, nalazi se znatno više grobalja sa kamenim

26 Дејан Булић - Радивоје Арсић, "Археолошко рекогносцирање општине Осечина", u: Glasnik Srpskog arheološkog društva, 35, Beograd, 2019, str. 195-235. 
Hercegovina - 6 - 2020., str. 63-98

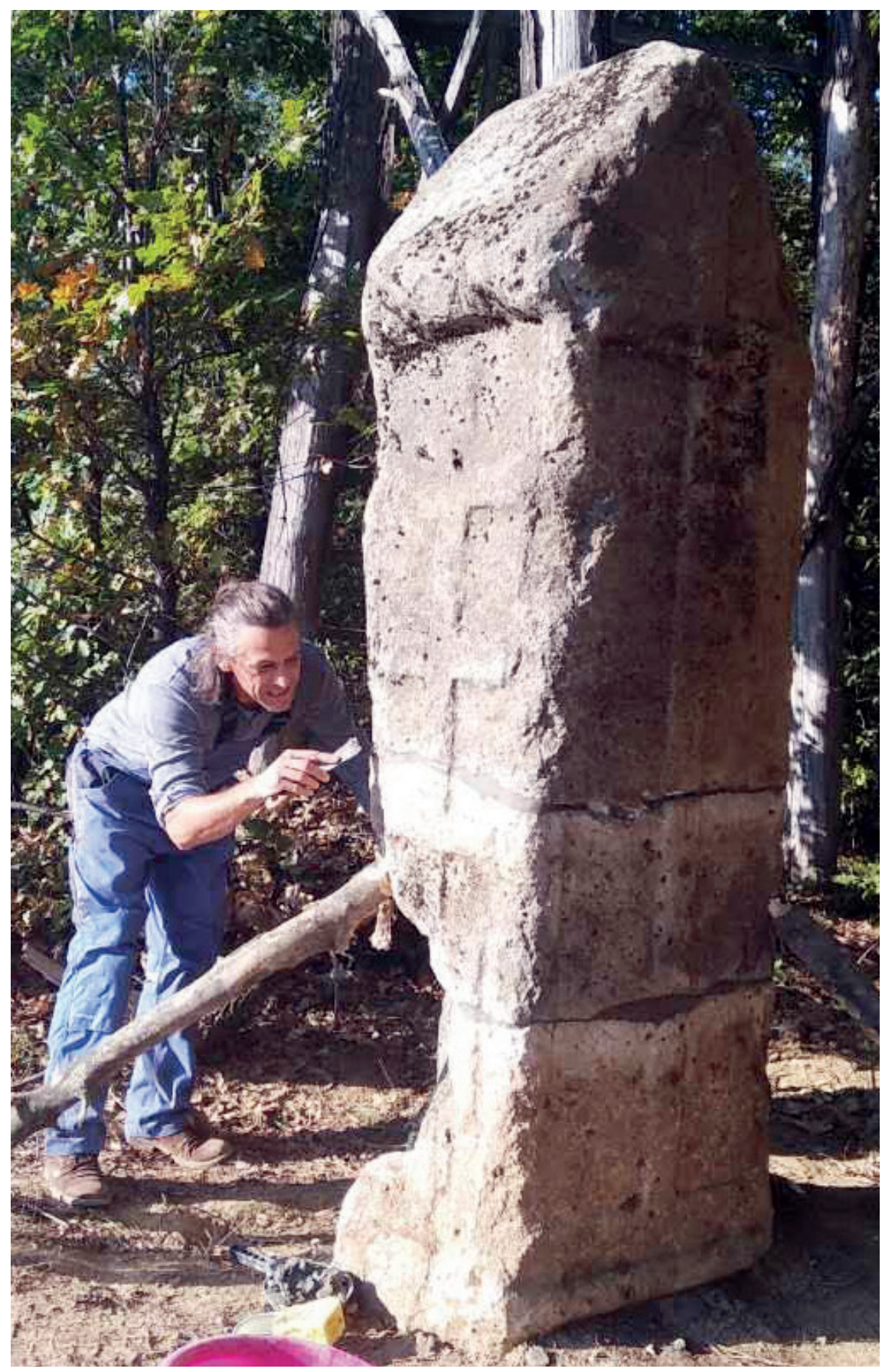

Slika 12. Lokalitet Veliki beleg, selo Miličinica u opštini Valjevo (foto D. Bulić) 
belezima od kojih su samo pojedina našla mesto u evidencijama stećaka i njihovo sistematsko evidentiranje i objavljivanje tek predstoji. ${ }^{27}$ Među njima se nalazi i veoma neobičan, usamljeni, masivan i izuzetno visok usadnik u selu Miličinica, na potesu Veliki beleg (opština Valjevo), zatečen polomljen, ispod koga još uvek nisu obavljena istraživanja kako bi se proverilo da li je obeležavao grob (slika 12). ${ }^{28}$

Sa teritorije opština na području starog Rasa, u jugozapadnoj Srbiji, posebno su brojne i karakteristične nekropole sa amorfnim pločama, koje uglavnom nisu iskopavane, a takve ploče se među stećcima smatraju najstarijim primercima. Upravo ova regija, odnosno teritorije današnjih opština Novog Pazara i delova susedne Raške, te i Sjenice i Tutina, spada među najsistematičnije rekognosciranu i istraživanu oblast kada je reč o srednjovekovnim grobljima i nadgrobnim spomenicima. ${ }^{29} \mathrm{U}$ kontekstu teme našeg rada pomenućemo samo jedno groblje sa mramorima sa te teritorije, koje nije ušlo u ranije evidencije nekropola stećaka, ali izaziva pažnju brojem i tipološkom raznolikošću spomenika (slika 13). Reč je o groblju sa kamenim nadgrobnim belezima koje meštani nazivaju Grčko groblje (uz savremeno groblje) u selu Ljuljac, severozapadno od Novog Pazara, koje je obilaženo i dokumentovano u više navrata, a poslednji put početkom zadnje decenije. ${ }^{30}$ Ovim poslednjim istraživanjima je očišćeno oko 100 spomenika i konstatovano da do-

27 Е. Зечевић, Мраморје, стећии западне Србије, str. 14 sa nap. 9. Poznato nam je takođe da je u diplomskom radu pod naslovom Srednjovekovni nadgrobni spomenici na teritoriji opštine Mali Zvornik (odbranjen daleke 2008. godine), koleginica Verica Tanasić evidentirala i dokumentovala ličnom opservacijom na terenu 15 grobalja na teritoriji ove opštine od kojih su pojedina bila tek registrovana u ranijim rekognosciranjima M. Vasiljevića, a reč je uglavnom o grobljima sa usadnicima kao dominirajućim oblikom spomenika koji nisu ušli u evidencije nekropola stećaka. Takođe, treba pomenuti i da su u toku rekognosciranja koja obavljaju saradnici Istorijskog instituta u Beogradu i Zavoda za zaštitu spomenika kulture Valjevo.

28 Zahvalnost za ustupljenu fotografiju i podatke o ovom spomeniku dugujem kolegi Dejanu Buliću iz Istorijskog instituta u Beogradu.

29 Odličan pregled istorijata istraživanja videti kod: J. Ердељан, nav. d., str. 1319. Izuzetno vredna u svakom pogledu, pa i po pitanju pregleda grobalja i nadgrobnih spomenika je pomenuta knjiga Dragice Premović-Aleksić, objavljena kao rezultat njenog višedecenijskog rada u muzeju "Ras" u Novom Pazaru (Д. Премовић-Алексић, nav. d.).

30 Д. Премовић-Алексић, nav. d., str. 74-76 sa starijom literaturom (lok. br. 124); ІsтА, "Средњовековна некропола у Љуљцу", u: Novopazarski zbornik, 34, Novi Pazar, 2011, str. 277-282. 


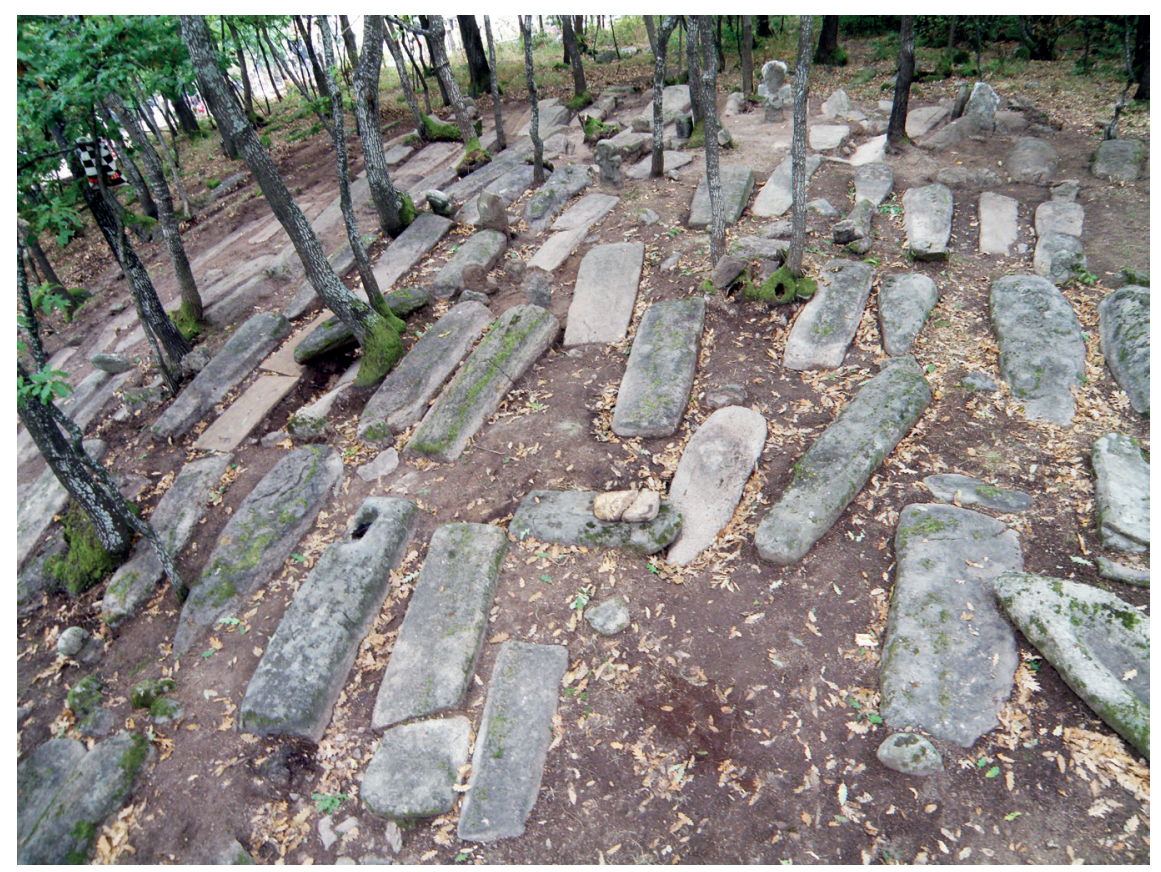

Slika 13. Lokalitet Grčko groblje, selo Ljuljac, pogled sa jugozapada

(foto D. Premović-Aleksić)

miniraju oblici ploča (kojih nema jedino na severnoj strani groblja) i usadnici u vidu ploče ili krstače (u mlađem delu groblja na severnoj i zapadnoj strani lokaliteta). Nekropola je obrazovana na redove, sa spomenicima u vrlo zbijenom rasporedu, redovno pravilno orijentisanim po pravcu zapad-istok sa manjim odstupanjima. Pokazalo se da se na groblju nalaze svi tipološki oblici do tada registrovani u oblasti Rasa. Najzastupljenije su ploče ravno klesanih površina, sa ili bez koso zasečenih gornjih ivica, i to najviše u južnom delu groblja. Masivniji i viši primerci, koji se tipološki mogu svrstati u sanduke, vertikalnih bočnih strana ili sa koso zasečenim gornjim ivicama, ređe u obliku kvadera, najbrojniji su u centralnom delu, ali i na istočnoj i severoistočnoj strani. Izdvojeno je i nekoliko slemenjaka, kao i spomenika tipa "riblja leđa" - ovoidnog tela i ispupčene gornje površine. Jedan spomenik ima specifičan i ređe zabeležen oblik koji podseća na telo ribe, sa isklesanim "očima" na bočnim stranama (slika 14 ). ${ }^{31}$ Groblje se izdvaja od ovdaš-

31 Njemu najsličniji je spomenik u obliku ribe sa ćiriličkim natpisom na hrbatu, otkriven prilikom iskopavanja oko obnovljene trikonhalne crkve $\mathrm{u}$ 


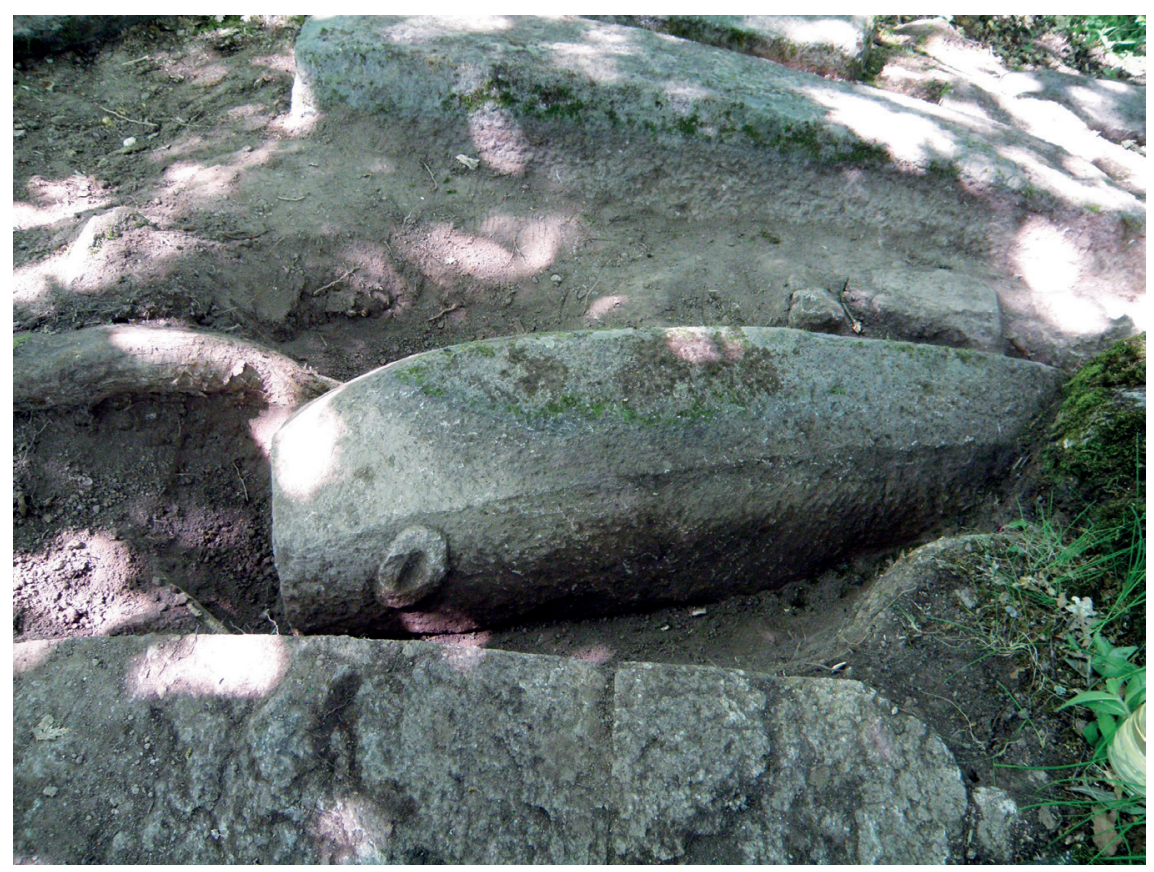

Slika 14. Lokalitet Grčko groblje, selo Ljuljac, "riboliki" spomenik (foto D. Premović-Aleksić)

njih grobalja po broju trodelnih nadgrobnih obeležja koja čine nekoliko kombinacija - horizontalni spomenik (ploča, sanduk ili tip "riblja leđa") sa po jednim usadnikom na zapadnom i istočnom kraju u vidu neobrađenog pločastog kamena; ${ }^{32}$ drugi tip kompozitnog obeležja čini manja krstača, sa reljefnim predstavama krstova na obe strane, postavljena na zapadnom kraju čelo glave i tzv. "srpski nišan" postavljen na istočnoj

Kuršumliji (jugoistočna Srbija, a srednjovekovna Toplica), koja se poistovećuje sa Bogorodičinom crkvom, jednom od dve prve zadužbine srpskog župana Stefana Nemanje. Zanimljivo tumačenje porekla i simbolike oblika ovog nadgrobnog belega, datovanog u 14. vek, izneo je Đorđe Janković (Ђopђe Јанковић, "Риболики надгробни споменик из Куршумлије", u: Mitološki zbornik, 20, 2009, str. 57-66).

32 Trostruki beleg sastavljen od položene (mermerne) ploče s natpisom i dva pločasta niža usadnika na njenim krajevima, koji se datuje u 14. vek, nalazi se u porti manastira Gradac (Aleksandra JurišIć, Градаu, - резултати археолошких радова, Republički zavod za zaštitu spomenika kulture Beograd, Beograd, 1989, str. 74, sl. 71/72 i DANica Popović, "Градачки надгробни натписи", u: Saopštenja, XXIV, Beograd, 1992, str. 53-54). 
strani horizontalnog spomenika (koji može imati uklesane stilizovane krstove, obrise lica, ljudske figure). Inače spomenik tipa "srpskog nišana" ima oblik stuba različitog preseka sa četiri kubična ispusta na uglovima, tik ispod poluloptasto oblikovanog vrha, inače dosta zastupljen oblik spomenika upravo u sklopu ovakve složene sepulkralne celine na lokalitetima u okruženju. ${ }^{33}$ Najmlađe spomenike čine velike krstače sa razvijenom predstavom krsta kao ukrasom (18. vek). Zaravnjeni plato uzvišenja na kome se nalazi groblje je sondiran 2011. godine u cilju otkrivanja crkve, čiji su se temelji ranije uočavali, i tom prilikom je podignuta jedna ploča na jugozapadnom uglu platoa. ${ }^{34}$ Otkriven je grob sa trošnim ostacima skeleta ograđenim kamenom, orijentacije zapadistok, bez priloga i bez drugih podataka, a kako iskopavanja ovde nisu nastavljena, ostali smo za sada bez mogućnosti upoređivanja sa drugim sahranama pod kamenim nadgrobnicima, što bi bilo veoma važno zbog kontinuiranog korišćenja groblja za sahranjivanje, smatra se 13-14. veka pa sve do danas.

Po pitanju najbolje istraženosti prednjače groblja sa kamenim spomenicima koji nisu zapravo kategorisani kao stećci, a reč je o pomenutim pločama sa grobalja formiranih oko crkvenih građevina ili unutar manastirskih porti, ređe naseobinskim, koje budući bez priloga često nisu uže datovane. Većina tih nadgrobnika, međutim, ima natpise na osnovu kojih je vršeno datiranje, ponekad i specifične ornamente po kojima ih možemo vezivati za spomenike u Bosni i Hercegovini. Navešćemo samo primer jedne varijante ploče, najizrazitije po brojnosti. Naime, ploče čija gornja površina ima zakošene (zasečene) ivice čine najbrojniju grupu spomenika sa srednjovekovnih lokaliteta u Srbiji, naročito karakterističnih za oblast starog Rasa, ali ih nalazimo i izvan teritorije jugozapadne Srbije. ${ }^{35}$ Reč je, uglavnom, o epigrafskim pločama, ponekad sa nekim

33 J. Ердељан, nav. d., str. 57-58 ("srpski nišani"), str. 59-62 (složene sepulkralne celine); up. Ista, "О српским нишанима на старим гробљима у околини Новог Пазара", u: Novopazarski zbornik, 18, Novi Pazar, 1994, str. 23-29; Ista, "Један особени вид надгробног обележја у области Старог Раса", u: Simpozijum Seoski dani Sretena Vukosavljevića, XVI, Prijepolje, 1995, str. 161172. "Srpski nišan" je jedini novi termin uveden u tipologiju nadgrobnih spomenika u Srbiji, ali se mora naglasiti da se odnosi na samo jedan određeni oblik usadnika, kao uostalom što se i termin slemenjak odnosi samo na određeni oblik mramora.

34 Д. Премовић-Алексић, Средюовековна некропола у љуљиу, str. 282.

35 J. Ердељан, Средюовековни надгробни споменици у области Раса, str. 43 (kao varijanta obrađenih položenih ploča ravne gornje površine), 44-45, 50- 
klesanim ornamentom, koje su prema natpisima (bez godina) datovane većinom u 14 . vek, ali i kraj 13, odnosno u prvu polovinu 15 . veka, retko kasnije. Klesane su i od peščara i krečnjaka (uglavnom bez natpisa i ukrasa) i stajale su nad monaškim grobovima nekropola formiranim oko manastirskih crkava, ali i nad laičkim grobovima ${ }^{36}$ u porti manastira, a sasvim retko nad ukopima unutar manastirskih crkvi. ${ }^{37}$ Međutim, samo pojedine ploče ovog oblika su se našle u Bešlagićevoj evidenciji stećaka iz Zapadne Srbije. Tako je na primer nekropola na potesu Grčko groblje u Dučevu (opština Prijepolje), na kojoj su zastupljeni samo amorfni i spomenici u obliku ploča i sanduka, a među njima i više primeraka zasečenih ivica, svrstana u nekropole stećaka verovatno "zahvaljujući" takvoj ploči sa natpisom koji pominje Desislavu i njenog sina koji joj podiže spomenik, ${ }^{38}$ za razliku od većine drugih grobalja na kojima su takođe zastupljeni samo ovi oblici, kao što smo naveli, uglavnom uz crkvene građevine koji se nisu našli u popisu grobalja sa stećcima.

Postoje i naseobinska groblja sa nekim osobenim oblicima nadgrobnika. $\mathrm{Na}$ nekoliko pomenutih lokaliteta sa teritorije Kosova i Metohije pojavljuju se na primer nadgrobne ploče specifičnog oblika koje se nisu našle u evidencijama stećaka, ali su upoređivane sa njima. Reč je o pločama uglavnom oblika trapeza u horizontalnoj projekciji, sa reljefnim krstom

51, 87-90 sa nap.; up. Е. Зечевић, Мраморје, стећии западне Србије, Tab. I/1-đ, str. 27, 31 sa nap. i IsTA, O nojmy сmeћaא, str. 148-149 sa nap. 11, gde su navedeni samo neki od lokaliteta na kojima se ova varijanta oblika ploče pojavljuje. Ima ih gotovo u svim delovima Srbije, doista u manjem broju nego u jugozapadnoj Srbiji.

36 Takav oblik ima ploča sa natpisom раба божија Анастасија, datovana u 13. vek i pripisana vlastelinki, kao i dve anepigrafske ploče sa ženskih grobova u manastiru Studenica u kojima je nađen nakit, datovane u 15. vek (Поповић Марко, Манастир Студениияа. Археолошка открића, Republički zavod za zaštitu spomenika kulture Beograd i Arheološki institut Beograd, Beograd, 2015, str. 78-79 sa nap. 254-258, 260).

$37 \mathrm{Na}$ primer nadgrobna ploča Marine Vitoslave iz 1374. godine, u priprati manastira Dečani na Kosovu i Metohiji (Даница Поповић, "Средњовековни надгробни споменици у Дечанима", у: Дечани и византијска уметност средином XIV века, Srpska akademija nauka i umetnosti, Beograd, 1989, str. 233, sl. 10), ili nadgrobna ploča Antonija jeromonaha u priprati crkve Svetog Nikole u manastiru Studenica iz 15. veka (IstA, "Средњовековне надгробне плоче у Студеници", у: М. Поповић, Манастир Студеница. Археолошка открића, Beograd, 2015, str. 387, T. V/4).

38 Š. BeŠLAgić, Stećci, kataloško-topografski pregled, str. 426. Up. Е. Зечевић, Мраморје, стећии западне Србије, str. 31, 78 (br. 10), 125 (lok. br. 86), crtež 72. 
na gornjoj površini, vrlo često u kombinaciji sa krstačom čelo glave ili sa krstačom čelo glave i usadnikom podno nogu. ${ }^{39}$ Prema pojavi istog tipa ploče na više grobalja u Kosovskoj kotlini opravdano se zaključuje da su rađene u istoj radionici. ${ }^{40}$ Poredeći ih prema obliku sa pločama iz Kalinovika i Blidinja (Bosna i Hercegovina), odnosno prema ukrasu na pločama tj. niskim slemenjacima sa reljefnim krstovima iz Janačkog polja (Srbija, Novi Pazar), koje su ušle u evidenciju stećaka, ${ }^{41}$ autori su zaključili da se i gornjobrnjičke ploče mogu datovati u 14-15. vek i da na to vreme upućuje i činjenica da ploča kombinovana sa krstačom "nije retka pojava u oblasti stećaka" u kojoj uostalom ima i stubova koji se usađuju čelo glave i podno nogu. ${ }^{42}$

U novije vreme su, takođe, izvan teritorije stećaka (zapadne Srbije) evidentirani još neki osobeni primerci nadgrobnih obeležja, koji sadrže izvesne elemente prema kojima se mogu porediti sa stećcima u Bosni i Hercegovini. Navešćemo samo tri primera. U centralnoj Srbiji (Pomoravlje), u selu Zdravinju, na oko $25 \mathrm{~km}$ jugoistočno od Kruševca, nađen je mramor u obliku masivnog oblutka s natpisom u kome se pominje i godina 1292 , koji pomera granice datovanja najstarijih kamenih nadgrobnika u ovom delu Srbije, ${ }^{43}$ naročito značajan i iz razloga što se tekst natpisa sa imenom pokojnika jasno iščitava (slika 15), dok nedaleko odatle u porti crkve Sv. Đorđa decenijama u travi leži nadgrobnik u čijem se natpisu, inače uklesanom sa obe strane ovog usadnika, pominje ime pokojnika, pisara, i godina 1473. U susednoj opštini Varvarin, u porti crkve Sv. Jovana Krstitelja, u selu Orašju, nalazi se ploča sa istrvenim natpisom (?) i shematizovanom antropomorfnom predstavom koja drži simbol dostojanstva, verovatno štap, kakve nalazimo na stećcima u

39 Д. Ђукић - М. Ивановић, nav. d., str. 21-24 i sl. 6, 11-15, 17-18; str. 57-66 i Tabla 1-3, str. 105-222.

40 Isto, str. 95.

41 Š. BeŠLAgIĆ, Stećci, kataloško-topografski pregled, str. 425; Е. Зечевић, Мраморје, стећии западне Србије, str. 128-129, lok. br. 92, plan 18 sa literaturom. Videti: Д. Премовић-Алексић, Археолошка карта Новог Пазара, Тутина и Сјенице, str. 34-36, lok. br. 30.

42 Д. Ђукић - М. Ивановић, nav. d., str. 92-96, skica 4.

43 Smatralo se da najstariji spomenik u Kruševačkom kraju predstavlja nadgrobni kamen nađen u kuli zvonika Crkve Lazarice (zadužbine kneza Lazara), koji datira s kraja 13. i početka 14. veka (Мирко Ковачевић, "Профана архитектура средњовековног Крушевца", у: Ђурђе Бошковић (ур.), Археолошка истраживаға Крушевияа и Моравске Србије, Arheološki institut Beograd, Beograd, 1980, str. 26, sl. 8). 
Emina Zečević - Nova saznanja i problemi u proučavanju mramora (stećaka)...

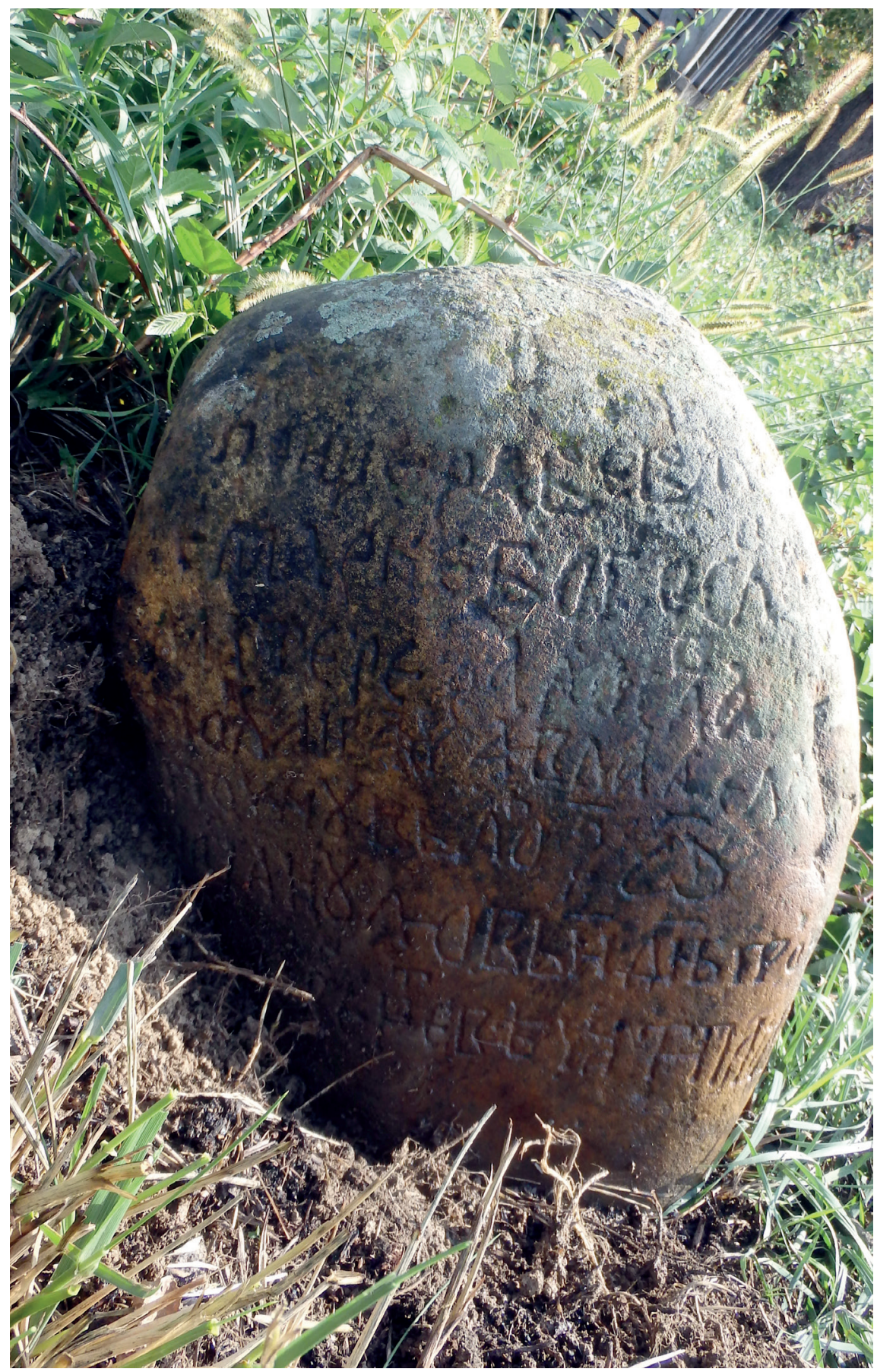

Slika 15. Spomenik sa natpisom i godinom 1292. iz sela Zdravinja (opština Kruševac) 


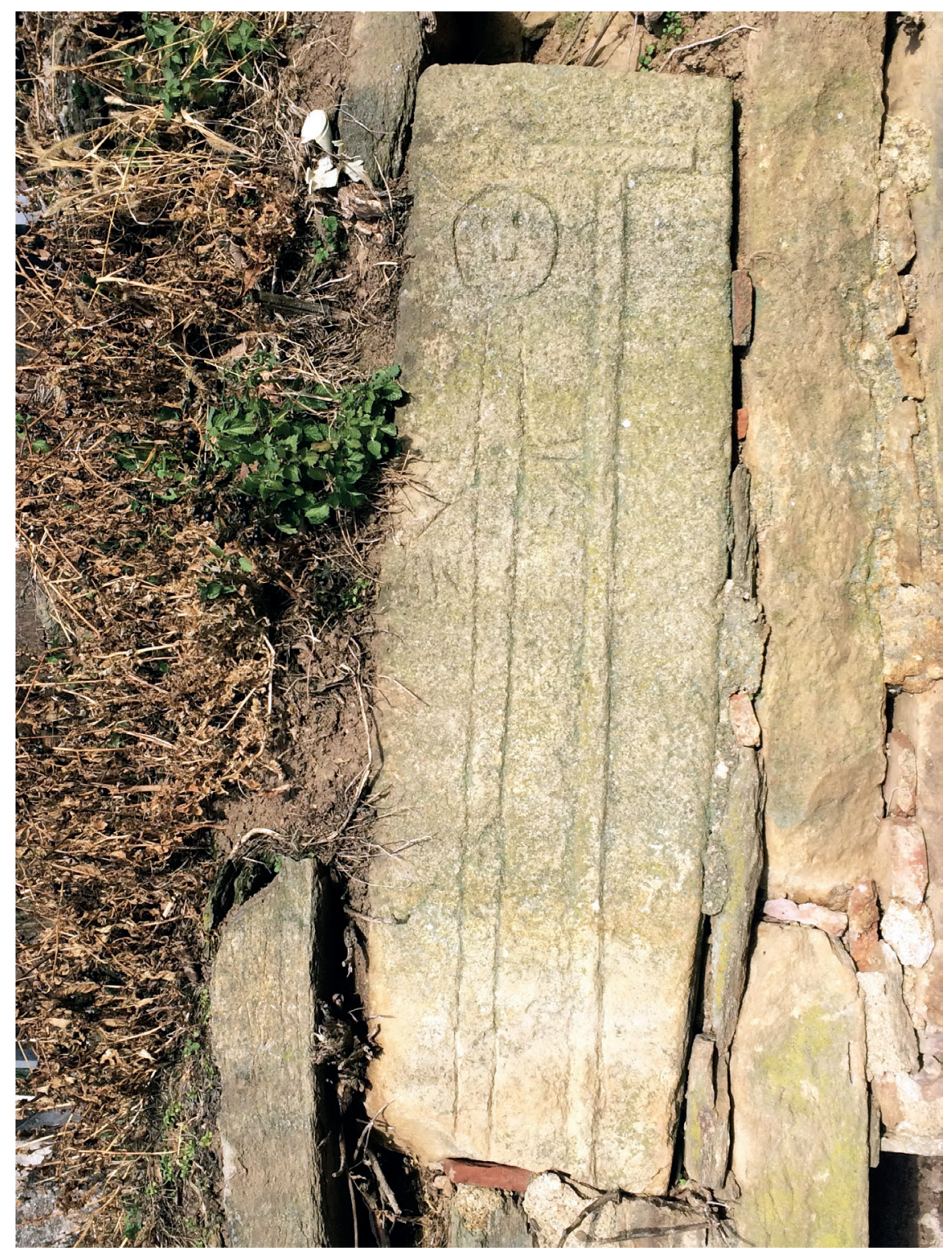

Slika 16. Ornamentisana ploča u porti crkve Svetog Jovana Krstitelja (selo Orašje, opština Varvarin) 
Bosni i Hercegovini (slika 16). ${ }^{44}$ I pored značajnih akcija različitih ustanova zaštite ova regija nije sistematski obrađena, niti građa objedinjena i publikovana, još od sredine prošlog veka. ${ }^{45}$

Rezimirajući naše izlaganje, vidimo da se iz ovih nekoliko primera arheološki istraživanih nekropola može zaključiti da nema bitnih razlika u odnosu na načine sahranjivanja, grobnu arhitekturu i nalaze u grobovima, zabeležene u nekropolama stećaka na teritoriji Bosne i Hercegovine, koja se smatra njihovom "matičnom" teritorijom. Takođe, iz ovog sumarnog pregleda izabranih primeraka spomenika videli smo da mramora, tj. monolitnih kamenih nadgrobnih spomenika, ima na celom području Srbije, a ne samo u zapadnoj Srbiji koja se navodi kao periferna teritorija pojave stećaka. Problem u njihovom proučavanju jeste duboko u vezi i sa činjenicom da do danas nije izvršena sistematska evidencija grobalja sa mramorima, niti jedinstvena klasifikacija oblika, kao što je to više puta isticano. Prema pregledu iz 1996. godine, za nadgrobne srednjovekovne monolite označene od strane istraživača terminom stećak, sa teritorije Srbije vezuje se broj od 4.118 spomenika sa 203 lokacija. ${ }^{46}$ To nije ni blizu realnog

44 Zahvaljujem se ovom prilikom kolegi Marinu Bugaru, iz Narodnog muzeja u Kruševcu, na ustupljenim fotografijama i podacima o ova tri nepublikovana spomenika.

45 Poslednja publikacija u kojoj je objedinjena građa koja se tiče srednjovekovnih nekropola i nadgrobnih spomenika u centralnoj Srbiji je izašla davne 1956. godine: Мирјана Ћоровић-Љубинковић, "Некрополе и гробни белези", у: Ђурђе Бошковић (прир.), Археолошки споменици и налазишта у Србији, II, Centralna Srbija, Srpska akademija nauka i umetnosti, Beograd, 1956, str. 231-261. Poznato nam je da su u međuvremenu vršena brojna rekognosciranja istog terena od strane različitih institucija, ali objedinjena topografija nalazišta nedostaje, kao ni kordinacija aktivnosti među ustanovama. Slična situacija je, nažalost, i sa drugim delovima Srbije na kojima se javljaju kameni nadgrobnici.

46 Е. Зечевић, Мраморје, стећии западне Србије, str. 23-24. Ovaj pregled spomenika i grobalja je sačinjen gotovo u celini na osnovu raspoložive publikovane i dostupne neobjavljene građe iz arhiva različitih ustanova, zaključno sa 1995. godinom. Sačinjen je na bazi pomena termina stećak u radovima istraživača koje smo uspeli pronaći. Do štampanja knjige (2005.) pa do danas, objavljen je još jedan broj tekstova i publikacija u kojima se pominju stećci, pod kojim se uglavnom podrazumevaju klasični oblici slemenjaka, takođe i oni belezi u obliku niskog slemenjaka i ploče sa ispupčenom gornjom površinom koji su svrstani u tip "riblja leđa" kao poseban tip položenih spomenika, ali i drugi tipovi nadgrobnog kamenja (Isto, 89 sa nap. 119; up. ovde nap. 1-2). 
brojnog stanja kamenih nadgrobnih spomenika na ovoj teritoriji, pre svega iz razloga koji smo naveli, a koji se tiče nedovoljne istraženosti i zanimanja za ovu vrstu spomeničkog nasleđa. Međutim, pravi razlog ovako malom broju u odnosu na kamene monolitne spomenike zapadno od Drine, jeste što se $\mathrm{u}$ tom popisu nisu našle brojne nekropole koje imaju uglavnom ploču, niski sanduk ili usadnik, kao jedini oblik spomenika, iako su jednovremeni stećcima sa područja Bosne i Hercegovine (12-16. veka). A to su belezi sa seoskih grobalja, uz crkvene građevine - pojedine vlasteoske i vladarske zadužbine - i mnoge manastirske crkve, kojih ima na celoj teritoriji Srbije, a ne samo u zapadnoj Srbiji. Najstariji pripadaju drugoj polovini 12. veka, odnosno nešto ranijem periodu, ${ }^{47}$ dok gornja granica zapravo ne postoji jer nije pouzdano utvrđeno da postoji prekid u postavljanju kamenih nadgrobnih spomenika do danas. Ovi spomenici su, dakle, $\mathrm{u}$ analizama ostali bez poređenja sa "stećcima" istog oblika, njihovom ornamentikom i natpisima, pa i grobnom arhitekturom i načinom sahranjivanja, prema kojima se uglavnom ne razlikuju.

Kako se to desilo? Svrstavanjem svih oblika srednjovekovnih nadgrobnih kamenih monolita sa tla Bosne i Hercegovine u kategoriju spomenika koja je dobila poseban naziv - stećak, nametnuto je poređenje sa istim oblicima kamenih spomenika sa okolnih teritorija. To je posledično proizvelo da se samo pojedini od njih nazivaju stećci$m a$, a drugi ne. Problem je, zapravo, nastao kod oblika ploče koja se pojavljuje na znatno široj teritoriji i u širem vremenskom okviru od onih u koje se svrstavaju stećci. Naime, iako su kameni spomenici u Srbiji klesani u različitim oblicima, najzastupljenije su upravo ploče,

47 Е. Зечевић, Мраморје, стећй западне Србије, str. 29-32 sa nap. Inače najstarijim pripadaju primerci ploče ugrađene u zidine tvrđave Ras na potesu Gradina kod Novog Pazara (Ј. Ердељан, Средюовековни надгробни споменици у области Раса, str. 96, sl. 23/1), ploče iz manastira Sv. Ahilije u Arilju (nadgrobne ploče iz prednemanjićkog horizonta sa jednom od njih nad grobom $222 \mathrm{u}$ kome je bila ovalna krupna jagoda naušnice datovane u 10-11. vek, up. Милка Чанак-Медић, Свети Ахилије у Арилу, историја, архитектура и просторни склоп манастира, Republički zavod za zaštitu spomenika kulture Beograd, Beograd, 2002, str. 77-79 i sl. 48, 260 i sl. 276), verovatno i neke iz najstarijeg horizonta sahranjivanja u manastiru Đurđevi Stupovi kod Novog Pazara, zadužbini Stefana Nemanje izgrađenoj 1170/71. godine (Јован Нешковић, Ђурђеви ступови у Старом Расу: постанак архитектуре иркве св. Борђа и ствараюе Рашког типа споменика у архитектури средюовековне Србије, Zavod za zaštitu spomenika kulture Kraljevo, Kraljevo, 1984, str. 19) i dr. 
sa natpisima ili bez njih, često sa ornamentikom koja se javlja i na stećcima u obliku ploča sa teritorije Bosne i Hercegovine, a pri tom ih ima na celoj teritoriji Srbije, dok je pojava osobenijih oblika, kao što je npr. Slemenjak, ograničena, kao što smo videli, uglavnom na zapadnu Srbiju. Da ponovimo, otuda su u Srbiji samo ploče (i usadnici) koje se javljaju na istim grobljima sa drugim karakterističnijim oblicima, kao što su slemenjaci, ili na primer ploče i sanduci sa postoljem - "sigurno" proglašeni stećcima. Većina istraživača iz Srbije ima i dalje takav pristup tipologiji i klasifikaciji nadgrobnih spomenika sa ove teritorije, dok svi oni koji su se bavili i bave se danas stećcima u Bosni i Hercegovini nisu imali problem prilikom određivanja koje su ploče sa tog područja stećci, jer kao što smo više puta naglasili, sva srednjovekovna groblja sa kamenim spomenicima proučavana su kao nekropole stećaka. Ipak se i kod Šefika Bešlagića, vrsnog poznavaoca ove tematike, pojavilo niz nedoumica, delom oprečnih mišljenja i nedoslednosti po pitanju koje ploče nazvati stećcima, pa tako i da li bi i ploče nad grobovima u crkvama trebalo svrstati $\mathrm{u}$ stećke, a takvih je u srpskim crkvama mnogo. ${ }^{48} \mathrm{Kad}$ je reč o upoređivanju ornamentike na spomenicima, problem se samo usložnjava s obzirom na višeznačnost i dugo "trajanje" većine ornamenata. Eto pitanja poput ovog - da li je stećak i ploča iz istočne Srbije ukoliko ima ornament koji se pojavljuje i na spomenicima u Bosni i Hercegovini? A znamo da nijedna ploča van balkanskog prostora, kakav god motiv da je imala, nije nazvana stećkom! Primera u kojima postoje nedoumice po pitanju "kategorizacije" spomenika sa teritorije Srbije, pa time i njihove tipološke definicije je mnogo, ali ćemo se zadržati na ovih nekoliko koje smo pobrojali, u pokušaju da se još jednom ukaže na moguće rešenje u pristupu problematici izučavanja srednjovekovnih nadgrobnih spomenika na teritoriji Srbije. Ono se svodi na stanovište da spomenike poznate pod nazivom stećak ne smemo proučavati kao "izolovanu" pojavu, odnosno "vrstu" spomenika, već upravo u njihovom najširem i osnovnom značenju srednjovekovnog kamenog nadgrobnog spomenika, kako bi smeštanjem u uži vremenski i teritorijalni okvir, kroz određen tipološki oblik (prema jasno

48 Š. BešLAGić, Kultura i umjetnost, str. 81. Up. Е. Зечевић, O појмy стећак, str. 147 i nap. 9. Iste nedoumice Š. Bešlagić ima i kada su u pitanju nadgrobni spomenici u obliku stubova (uglavnom pločastih), za koje tvrdi da je izvesno da su klesani i posle razdoblja stećaka, zatim da su samo neki uvršteni u steć$k e$, dok se za neke stećke-stubove pita da li su možda klesani i postavljani u vremenu posle perioda stećaka (Š. BEŠLAGIć, Kultura i umjetnost, str. 551). 
definisanoj klasifikaciji), oni mogli biti proučavani kao deo korpusa srednjovekovnih spomenika na široj teritoriji. Iz upoređivanja oblika spomenika sa svim elementima koji sa njim čine celinu (ornamentika, grob - grobna arhitektura i način sahranjivanja, pogrebni običaji, nalazi i dr.), proizaći će regionalne različitosti i sličnosti. Činjenica je da će rezultati biti u većini slični onim do kojih su došli Šefik Bešlagić i drugi istraživači, kada je reč o srodnosti spomenika, tj. specifičnostima određenih regija, ali isto tako dobićemo jedinstvenu tipologiju spomenika zasnovanu na osnovnim oblicima i njihovim varijantama na celoj teritoriji centralnog Balkana, tj. bivših jugoslovenskih republika, na kojima su formirane matične srednjovekovne države naroda koji i danas tu žive. Nema sumnje da važan preduslov u svemu tome predstavlja plansko i sistematsko evidentiranje, odnosno dokumentovanje i publikovanje nekropola sa mramorima, uz uspostavljanje tipologije oblika. Ono će omogućiti da se pouzdanije uspostavi i hronologija nastanka i trajanja pojedinih tipova spomenika, odnosno sagleda njihova pojava u istorijskom i socijalnom kontekstu. Gotovo da nema istraživača koji nije ukazivao na potrebu i nužnost takvog pristupa ovoj vrsti srpskog nasleđa, ali, nažalost, takav projekat još uvek nije realizovan.$^{49}$ Jedan od razloga je i taj što u proučavanju kamenih nadgrobnih monolita, ne samo u Srbiji, nedostaje veća arheološka istraženost grobalja, posebno onih sa masivnijim primercima mramora čije je iskopavanje zahtevno i u tehničkom smislu. Ne manji problem predstavljaju groblja na kojima su jedini oblici spomenika usadnici i krstače, budući da apriori ostaju izvan interesovanja arheologa, a nužni su radi uspostavljanja hronoloških i morfoloških odnosa među svim oblicima nadgrobnika.

Neki specifični oblici nadgrobnih belega i novootkriveni natpisi iziskuju još neke odgovore. Izostavljajući po strani ornamentiku tj. poreklo i simboliku motiva, pripadnost spomenika i druge teme kojih se nismo dotakli, završićemo izlaganje sa još uvek aktuelnim pitanjima na koja nemamo potpune odgovore, a koji bi nam pomogli pri donošenju zaključaka na temu srednjovekovnih kamenih nadgrobnih obeležja na teritoriji centralnog Balkana. Neka od njih su: šta je reper pri određivanju gornje granice trajanja određenih oblika stećaka u Bosni i Hercegovini? Kako izgledaju tamošnji spomenici

49 Е. Зечевић, Мраморје, стећии западне Србије, str. 176-180; J. Ердељан, Средюовековни надгробни спомениии у области Раса, str. 10, 19, 41; Ж. Јеж, nav. d., str. 135 itd. 
Emina Zečević - Nova saznanja i problemi u proučavanju mramora (stećaka)...

hrišćana podizani posle perioda stećaka? Da li ornamentika može biti presudna kada se govori o "tradiciji klesanja stećaka", budući da samo pojedini motivi predstavljaju osobitost određenog podneblja i da je trajanje drugih često nesagledivo? $\mathrm{Na}$ šta se zapravo termin stećak odnosi? 


\title{
New findings and problems in studying marble (stecaks) from the territory of Serbia
}

\author{
Summary
}

Only a couple of graveyards with marbles recorded as stecaks necropolises went through probe archeological excavations in the last decade in the area of western Serbia, which is in professional and scientific circles marked as the territory of stecaks. Among them there are three necropolises carrying the same toponym in the name - Mramorje - in Middle Podrinje (Municipality of Bajina Basta), map 2, images 1-7. Results of their excavations, as well as for the first time published results of earlier excavations of two necropolises with marbles in Donje Polimlje (Municipality of Priboj) in southwestern Serbia (images 8-10) offered new insights and confirmation of the earlier in terms of the form of burial, dating and existence of the Church next to the graveyard with typical late medieval forms of monuments. At the same time they renewed the issues around studying stecaks from Serbia, which appeared with adopting of that term for all tombstone monoliths in Bosnia and Herzegovina that were being studied as a special "type" of monuments in relation to the monuments in the region. The result of this was that all graveyards in Serbia which contained gabled tombstone were treated as stecaks necropolises (map 1), while only some of the numerous tombstones of other forms but from the same period were classified as stecaks. Others with the same form were not classified in that way, although there is an obvious similarity between them especially in regards to ornaments, content of epitaphs or the form of burial. Those are numerous registered monuments in the form of boards, low coffins and butts and their variant forms from the village graveyards or graveyards formed next to church buildings, some feudal endowments and many monastery churches from the entire territory of Serbia, which were studied without comparison to phenomena related to stecaks. 
According to the last listing (1996) 4.118 medieval tombstone monoliths (from 203 sites) labelled by the term stecak come from the territory of Serbia. That is not even close to the real number of tombstones in Serbia due to the above mentioned reasons. Discoveries of the new monuments and locations with medieval tombstones in the systematic surveys conducted in the entire territory of Serbia (images 11-16), showed that among them there were types of tombstones specific for certain regions, but also those which could be connected to stecaks according to certain elements. They pointed out the necessity of systematic registration and establishment of the unique typology of the monument forms in the entire territory of central Balkan, which should be treated under the general determinant of the medieval tombstones characteristics. They also draw attention to the necessity of archaeological excavations under marbles and including interdisciplinary research, as well as reviewing the justification of not only the categorizations through which stecaks entered into science but also of the term stecak.

Keywords: Serbia; graveyards; stecaks or marbles of different forms; late Middle Ages. 